\title{
Microbial co-occurrence patterns in deep Precambrian bedrock fracture fluids
}

\author{
Lotta Purkamo $^{1}$, Malin Bomberg ${ }^{1}$, Riikka Kietäväinen ${ }^{2}$, Heikki Salavirta ${ }^{1}$, Mari Nyyssönen ${ }^{1}$, \\ Maija Nuppunen-Puputti ${ }^{1}$, Lasse Ahonen $^{2}$, Ilmo Kukkonen ${ }^{2, \text { a }}$, and Merja Itävaara ${ }^{1}$ \\ ${ }^{1}$ VTT Technical Research Centre of Finland Ltd., Espoo, Finland \\ ${ }^{2}$ Geological Survey of Finland (GTK), Espoo, Finland \\ ${ }^{a}$ now at: Department of Physics, University of Helsinki, Helsinki, Finland \\ Correspondence to: Lotta Purkamo (lotta.purkamo@gmail.com)
}

Received: 13 September 2015 - Published in Biogeosciences Discuss.: 11 November 2015

Revised: 18 April 2016 - Accepted: 13 May 2016 - Published: 30 May 2016

\begin{abstract}
The bacterial and archaeal community composition and the possible carbon assimilation processes and energy sources of microbial communities in oligotrophic, deep, crystalline bedrock fractures is yet to be resolved. In this study, intrinsic microbial communities from groundwater of six fracture zones from 180 to $2300 \mathrm{~m}$ depths in Outokumpu bedrock were characterized using high-throughput amplicon sequencing and metagenomic prediction. Comamonadaceae-, Anaerobrancaceaeand Pseudomonadaceae-related operational taxonomic units (OTUs) form the core community in deep crystalline bedrock fractures in Outokumpu. Archaeal communities were mainly composed of Methanobacteriaceae-affiliating OTUs. The predicted bacterial metagenomes showed that pathways involved in fatty acid and amino sugar metabolism were common. In addition, relative abundance of genes coding the enzymes of autotrophic carbon fixation pathways in predicted metagenomes was low. This indicates that heterotrophic carbon assimilation is more important for microbial communities of the fracture zones. Network analysis based on cooccurrence of OTUs revealed possible "keystone" genera of the microbial communities belonging to Burkholderiales and Clostridiales. Bacterial communities in fractures resemble those found in oligotrophic, hydrogen-enriched environments. Serpentinization reactions of ophiolitic rocks in Outokumpu assemblage may provide a source of energy and organic carbon compounds for the microbial communities in the fractures. Sulfate reducers and methanogens form a minority of the total microbial communities, but OTUs forming
\end{abstract}

these minor groups are similar to those found in other deep Precambrian terrestrial bedrock environments.

\section{Introduction}

The microbial communities in deep terrestrial subsurface biosphere contribute significantly to the overall biomass on Earth (Whitman et al., 1998; McMahon and Parnell, 2014). It is essential to understand the metabolic capacity and energy sources of the microbial communities in deep biosphere in order to evaluate their role in global biogeochemical cycles, assess the risks these communities might cause to for example geological long-term storage of nuclear waste, and even estimate the possibility of microbial life in deep subsurface of other planetary bodies. In general, chemolithoautotrophic organisms are thought to be the primary producers in deep crystalline rock environments, into which sunlight, organic carbon or oxygen produced in photosynthesis do not penetrate (Gold, 1992; Pedersen, 1997, 2000). Therefore, energy and carbon sources for deep biosphere have to be geochemical. The most important source of reducing power in deep subsurface is $\mathrm{H}_{2}$. It is produced in abiotic reactions such as through radiolysis of $\mathrm{H}_{2} \mathrm{O}$ and in water-rock interactions such as serpentinization, but also by microbial activity (Pedersen, 2000; Lin et al., 2005; McCollom, 2013; Szponar et al., 2013). Carbon sources for microbes in deep subsurface are usually in the form of $\mathrm{CO}_{2}, \mathrm{CH}_{4}$ or other small hydrocarbons. Abiotic synthesis of organic carbon may take place through Fischer-Tropsch-type reactions and provide a 
photosynthesis-independent carbon source for heterotrophic organisms in deep terrestrial biosphere (Proskurowski et al., 2008; McCollom et al., 2010; Etiope and Sherwood Lollar, 2013; Kietäväinen and Purkamo, 2015). This process may be triggered and enhanced by continuous $\mathrm{H}_{2}$ flux provided by, for example, serpentinization. Numerous studies have characterized microbial communities of deep Precambrian rock formations (e.g. Pedersen, 1996; Petersen et al., 2008; Hallbeck and Pedersen, 2008, 2012; Lin et al., 2006; Gihring et al., 2006; Silver et al., 2010; Itävaara et al., 2011; Nyyssönen et al., 2012; Purkamo et al., 2013, 2015; Osburn et al., 2014; Bomberg et al., 2015a, b). Although some of these studies have explored the energy and carbon sources or electron accepting processes in these environments, attention has been focused mainly on chemoautotrophic organisms utilizing $\mathrm{H}_{2}$ and $\mathrm{CO}_{2}$. After all, abiotic synthesis of organic carbon could also provide a photosynthesis-independent source of carbon and thus support heterotrophic organisms in deep biosphere (Amend and Teske, 2005; Schrenk et al., 2013). However, heterotrophic involvement to the carbon cycling and energy production in the deep continental bedrock biosphere has been rather neglected (Amend and Teske, 2005), although it was recently suggested that heterotrophy might play a significant role in deep fluids of Fennoscandian crystalline rock (Purkamo et al., 2015).

While the microbial communities in deep marine subsurface environments have been intensively characterized within the last decade with next-generation sequencing methods (Sogin et al., 2006; Biddle et al., 2008, 2011; Brazelton et al., 2012), high-throughput (HTP) sequencing techniques have only recently emerged in characterization of the terrestrial deep subsurface microbial communities (Nyyssönen et al., 2014; Bomberg et al., 2014, 2015a, b; Lau et al., 2014; $\mathrm{Mu}$ et al., 2014). A vast amount of data obtained from HTP sequencing studies can be used to estimate ecological measures such as species richness, abundance and $\beta$-diversity, but it also allows the exploration of significant relationships between microbial taxa and their coexistence in a specific environment (Zhou et al., 2011; Barberan et al., 2012; Lupatini et al., 2014). These co-occurrence patterns, i.e. interactions between different microbial taxa and the complexity of the microbial communities, can significantly contribute to the processes that will take place in the ecosystem (Zhou et al., 2011). In addition, keystone organisms can be identified from co-occurrence patterns of the community (Steele et al., 2011). Keystone organisms often have a greater role in the ecosystem functionality than their abundance refers (Power et al., 1996). For example, in hydrogen-driven lithoautotrophic ecosystems, autotrophic methanogens can be responsible for primary production of the whole ecosystem (Pedersen, 2000; Nealson et al., 2005). Moreover, these diverse minority groups with low abundance, i.e. the socalled rare biosphere, can be an almost infinite source of genetic potential to be distributed through the microbial populations via gene transfer (Sogin et al., 2006).
In this study, we used high-throughput amplicon sequencing, metagenome prediction and co-occurrence analysis (1) to describe the microbial community structure, (2) to detect key microbial genera of deep fracture fluids in Outokumpu, (3) to evaluate the possible carbon assimilation processes taking place in deep bedrock, and ultimately (4) to understand the origin of carbon and energy sources in Outokumpu Palaeoproterozoic deep bedrock and to establish links between microbial communities and the geology and geochemistry in Outokumpu crystalline rock biosphere. Groundwater samples were collected from six different fracture zones located at depths ranging from 180 to $2300 \mathrm{~m}$, and we characterized bacterial and archaeal communities in these fractures by their 16S rRNA genes and transcripts. In addition, we characterized two functional groups carrying out important electron-accepting processes in deep subsurface, namely sulfate reduction and methanogenesis by dissimilatory sulfite reductase and methyl-coenzyme M reductase genes, respectively.

\section{Materials and methods}

\subsection{Sample collection and geochemistry}

Deep subsurface fracture fluids were collected during the years 2009-2011 from the Outokumpu Deep Drill Hole, eastern Finland. The sampling was conducted from overall six depths, 180, 500, 967, 1820, 2260 and $2300 \mathrm{~m}$, as described previously (Purkamo et al., 2013). Briefly, $967 \mathrm{~m}$ and shallower depths were packer-isolated and purged for 21-42 days, and deeper fractures were sampled with slow continuous pumping of the fluid from the fracture depth for 963 days in order to flush the drill hole. Care was taken to ensure that the pumping rate did not exceed the rate of inflow from the fracture zone. The hydrogeological characteristics of these fluids differ with depth (Table 1). Kietäväinen et al. (2013) described five different water types in Outokumpu, and the fracture zones in this study represent the types I (180 m), II (500 and $967 \mathrm{~m})$, IV (1820 and $2260 \mathrm{~m})$ and V $(2300 \mathrm{~m})$. The type I water is characterized with high $\mathrm{pH}$ (around 10) and higher alkalinity than other water types in Outokumpu. High $\mathrm{pH}$ in the drill hole water column probably originates from cementation within the uppermost $200 \mathrm{~m}$ of the drill hole, while during long-term pumping of the $180 \mathrm{~m}$ fracture zone, $\mathrm{pH}$ dropped to the level of 8.5. Water type II contains the highest amount of dissolved gases in the whole water column, of which approximately $75 \%$ (22$32 \mathrm{mmol} \mathrm{L}^{-1}$ ) is methane. A distinctive greenish colour and unpleasant "rotten egg" odour are typical for water type IV, indicating presence of reduced sulfur compounds. Water type $\mathrm{V}$ also has special features, such as high $\mathrm{K}$ and Li concentration due to the interaction with surrounding granitic rocks. In addition, the dominant dissolved gases in the two deepest water types IV and $\mathrm{V}$ are $\mathrm{He}$ and $\mathrm{H}_{2}$, in contrast to the $\mathrm{CH}_{4}$ - 
Table 1. Hydrogeochemical characteristics of six fracture zones of Outokumpu. Concentrations for cations and anions are given in mg $\mathrm{L}^{-1}$, $\mathrm{EC}$ in $\mathrm{mS} \mathrm{m}^{-1}$ and alkalinity in $\mathrm{mmol} \mathrm{L}^{-1}$.

\begin{tabular}{|c|c|c|c|c|c|c|c|c|c|c|c|c|c|c|c|c|c|c|}
\hline Depth m & Prevalent rock type & $\mathrm{Ca}$ & $\mathrm{Fe}$ & $\mathrm{Mg}$ & $\mathrm{Na}$ & $S$ & $\mathrm{Br}$ & $\mathrm{Cl}$ & $\mathrm{SO}_{4}$ & $\mathrm{NO}_{3}$ & Sulfide & TOC & DOC & TIC & DIC & $\mathrm{pH}$ & $\mathrm{EC}^{1}$ & Alkalinity \\
\hline 180 & Mica schist, biotite gneiss & 1060 & 0.34 & 16.7 & 1070 & 1.27 & 23 & 3280 & 1.5 & $<20$ & 0.057 & 12.8 & 9 & 0.7 & 0.6 & 7.4 & 1060 & 0.31 \\
\hline 500 & Chlorite-sericite schist & 2250 & $<0.03$ & 12.9 & 1810 & 3.49 & $<50$ & 8180 & 1.0 & $<100$ & b.d. & b.d. & b.d. & b.d. & b.d. & 8.3 & 1900 & 0.19 \\
\hline 967 & Mica schist, chlorite-sericite schist & 2000 & $<0.03$ & 0.8 & 1770 & 17.1 & 62.2 & 5790 & 0.6 & $<40$ & b.d. & 6.93 & 6.4 & $<0.2$ & $<0.2$ & 8.9 & 1740 & 0.29 \\
\hline 1820 & Mica and black schist, granite & 11800 & 0.03 & 15.1 & 3820 & 44.4 & 159 & 30300 & 2.6 & $<200$ & 0.87 & 30.33 & 29.7 & 0.4 & 0.51 & 9.0 & 6930 & 0.37 \\
\hline 2260 & Biotite gneiss & 8130 & 0.03 & 21 & 2630 & 4.8 & $<1000$ & 16400 & $<2$ & $<2000$ & b.d. & b.d. & b.d. & b.d. & b.d. & 8.2 & 4890 & 0.25 \\
\hline 2300 & Mica schist, granite & 9480 & $<0.03$ & 18.7 & 3120 & 7.42 & 123 & 24500 & $<2$ & $<200$ & 0.086 & 34.33 & 34 & 0.4 & $<0.2$ & 8.6 & 4370 & 0.29 \\
\hline
\end{tabular}

dominated water types above $2 \mathrm{~km}$ depth (Kietäväinen et al., 2013).

The fluid from each fracture zone was collected in the field into sterile, acid-washed glass bottles (Schott) in an anaerobic chamber (MBRAUN, Germany). The anaerobic conditions in the chamber were achieved as previously described (Purkamo et al., 2013). The biomass for RNA and DNA extraction was collected on nitrocellulose acetate filters (Corning Inc., NY, USA) from $3 \times 1$ and $3 \times 0.5 \mathrm{~L}$ of fracture fluid by vacuum suction. The filter was cut from the filter funnel with a sterile scalpel and placed immediately to dry ice in a sterile $50 \mathrm{~mL}$ plastic tube (Corning Inc., NY, USA). In the laboratory, the samples were preserved at $-80^{\circ} \mathrm{C}$ before processing. In addition, duplicate $100 \mathrm{~mL}$ fluid samples for microbial cell enumeration were obtained from each fracture zone. Sterile, acid-washed $120 \mathrm{~mL}$ serum bottles were flushed with a small amount of fracture fluid in the anaerobic cabinet and subsequently filled with $100 \mathrm{~mL}$ of the sample fluid, capped with butyl rubber stoppers, sealed with aluminium crimp caps and kept refrigerated until further processing in the laboratory within 5 days after the sampling.

\subsection{Enumeration of the total number of microbes}

In order to calculate the total number of microbes in fracture fluids, microbes were stained with 4'-6-diamidino-2phenylindole (DAPI). Preparation of the duplicate samples for examination by microscopy was conducted as in Purkamo et al. (2013). Stained microbes were collected from $5 \mathrm{~mL}$ fracture fluid samples by filtering, rinsed, and the filter was placed on a microscopy slide. The total cell number in the samples was based on the sum of counted cells and the effective area of the filter divided by volume of filtrated sample, number of randomly selected microscopy fields and the surface area of the field at $100 \times$ magnification.

\subsection{Nucleic acids preparation}

DNA and RNA were extracted from the biomass with a PowerSoil DNA or PowerWater RNA extraction kit (MO BIO Laboratories Inc., CA, USA) as previously described (Purkamo et al., 2013). An additional DNase treatment was applied to RNA extracts that had DNA contamination detected by PCR performed with P1 and P2 primers for the bacterial 16S rRNA gene (Muyzer et al., 1993) as previ- ously described in Purkamo et al. (2013). RNA was reversetranscribed in triplicate reactions with random hexamers using the Superscript III Reverse Transcriptase kit (Invitrogen, Thermo Fisher Scientific, MA, USA) as described in Purkamo et al. (2013). The triplicate reactions were pooled and subsequent cDNA as well as DNA were stored at $-80^{\circ} \mathrm{C}$. Negative controls for reagents were included in every extraction and translation step.

\subsection{Quantitative estimation of bacterial and archaeal communities}

The bacterial and archaeal numbers in each fracture were estimated with quantitative PCR from DNA extracts. The $16 \mathrm{~S}$ rRNA gene copy number was used as a proxy of the quantity of bacteria and archaea. In addition, qPCR was conducted to calculate the abundance of genes representing the key metabolic processes in anaerobic subsurface environments, namely sulfate reduction and methanogenesis with dissimilatory sulfite reductase $(d s r B)$ and methyl-coenzyme $\mathrm{M}$ reductase $(\mathrm{mcrA})$ genes, respectively. Bacterial 16S rRNA gene copy numbers were determined with $\mathrm{V} 3$ region-targeted primers P1 and P2 (Muyzer et al., 1993) resulting in a $190 \mathrm{bp}$ product. A $370 \mathrm{bp}$ fragment of the $d s r B$ gene and transcript was amplified with the primer pair DSRp2060f and DSR4R (Wagner et al., 1998; Geets et al., 2006). Archaeal 16S rRNA genes were amplified with ARC344f (Bano et al., 2004) and Ar774r (modified from Barns et al., 1994) primers producing a $430 \mathrm{bp}$ product. A $330 \mathrm{bp}$ fragment of the $m c r A$ gene was amplified with the primer pair ME1 and ME3rc (Hales et al., 1996; Nyyssönen et al., 2012).

Bacterial 16S rRNA gene-targeted qPCR was performed in triplicate reactions of each sample with $\mathrm{KAPA}^{\mathrm{TM}} \mathrm{SYBR}^{\circledR}$ Fast $2 \times$ Master Mix for Roche LightCycler 480 (Kapa Biosystems Inc., MA, USA) and $0.3 \mu \mathrm{M}$ each of forward and reverse primer. The qPCR was performed on a Roche LightCycler 480 (Roche Applied Science, Germany) on white 96well plates (4titude, UK) and sealed with transparent adhesive seals (4titude, UK). The qPCR conditions consisted of an initial denaturation at $95^{\circ} \mathrm{C}$ for $10 \mathrm{~min}$ followed by 45 amplification cycles of $15 \mathrm{~s}$ at $95^{\circ} \mathrm{C}, 30 \mathrm{~s}$ at $55^{\circ} \mathrm{C}$ and $30 \mathrm{~s}$ at $72^{\circ} \mathrm{C}$ and a final extension step of $3 \mathrm{~min}$ at $72^{\circ} \mathrm{C}$. After the quantification analysis, the melting curves for each reaction were determined. The melting curve analysis consisted of a 
denaturation step for $10 \mathrm{~s}$ at $95^{\circ} \mathrm{C}$ followed by an annealing step at $65^{\circ} \mathrm{C}$ for $1 \mathrm{~min}$ prior to a gradual temperature rise to $95^{\circ} \mathrm{C}$ at a rate of $0.11^{\circ} \mathrm{C} \mathrm{s}^{-1}$ during which the fluorescence was continuously measured. Amplification of $d s r B$, archaeal 16S rRNA and $m c r A$ genes were performed in triplicate for each sample as described in Purkamo et al. (2013), Bomberg et al. (2015a) and in Nyyssönen et al. (2014), respectively. The gene copy numbers were calculated by comparing the amplification result to a standard dilution series. Bacterial 16S rRNA and $d s r B$ gene copy numbers were determined in each sample by comparing the amplification result to a standard dilution series ranging from 0 to $10^{7}$ of plasmid DNA containing the 16S rRNA gene of Escherichia coli ATCC 31608 or from $1.5 \times 10^{1}$ to $1.5 \times 10^{7}$ copies of the Desulfobulbus propionicus DSM $2554 d s r B$ gene, respectively. Archaeal 16S rRNA and mcrA gene copy numbers were determined by comparing the amplification result to a dilution series of genomic DNA of Halobacterium salinarum DSM 3754 or to 5 to $5 \times 10^{6}$ copies of the Methanothermobacter thermautotrophicus DSM 1053 mcrA gene, respectively. Notemplate controls as well as nucleic acid extraction and translation reagent controls were analysed with the corresponding samples in the same run. The inhibition effect of the samples was evaluated by mixing a specified amount of standard dilution to each sample DNA or cDNA. Spiked reactions were then subsequently amplified using the same protocols as described above. The inhibition in each sample could be evaluated by comparing the amplification efficiency of the samplespiked standard DNA to the corresponding standard dilution quantity in the standard curve. Inhibition was found to be low in all samples (data not shown).

\subsection{High-throughput amplicon sequencing}

PCR amplicon libraries from hypervariable region V1-V3 of the bacterial 16S rRNA gene were generated with barcoded $8 \mathrm{f}$ and P2 primers (Edwards et al., 1989; Muyzer et al., 1993). Amplification of the $d s r B$ gene fragment for dissimilatory sulfate reduction was done with $2060 \mathrm{f}$ and $4 \mathrm{R}$ primers with barcode sequences (Wagner et al., 1998; Geets et al., 2006). Archaeal libraries were produced with nested PCR method, first using A109f and A915r primers (Großkopf et al., 1998, and Stahl, 1991, respectively) to amplify a ca. 800 bp long fragment of the archaeal 16S rRNA gene and using the resulting product as template in PCR reaction with barcoded A344f and A744 primers (Bano et al., 2004, and modified from Barns et al., 1994, respectively). McrA amplicons were also produced with nested PCR, first applying mcrA463f and mcrA1615r primers (Nyyssönen et al., 2012) and secondly barcoded primers Me1 and Me3 (modified from Hales et al., 1996). PCR reaction mix composed of one unit of proofreading Phusion DNA Polymerase (Thermo Scientific), $1 \times$ high-fidelity buffer and dNTP mix $(2.5 \mathrm{mM}$ each), filled to $50 \mu \mathrm{L}$ with molecular biological-grade $\mathrm{H}_{2} \mathrm{O}$. Dimethylsulfoxide was used in all PCR reactions to enhance the template availability to polymerase. The amplification cycle consisted of an initial denaturation at $98^{\circ} \mathrm{C}$ for $30 \mathrm{~s} ; 35$ (bacteria and $d s r B$ ), 30 (for the first PCR) or 40 (for the second PCR; archaea and $m c r A$ ) repetitions of $10 \mathrm{~s}$ at $98^{\circ} \mathrm{C} ; 15 \mathrm{~s}$ at $55^{\circ} \mathrm{C}$ and $30 \mathrm{~s}$ at $72^{\circ} \mathrm{C}$; and a final extension step of $5 \mathrm{~min}$ at $72^{\circ} \mathrm{C}$. Three samples were used for each fracture zone community (RNA or DNA) and two amplification reactions of each sample replicate, thus resulting in a maximum of six positive reactions (verified with agarose gel electrophoresis). Successful reactions were pooled prior to sequencing. PCR reactions were also performed for nucleic acid extraction and reagent control samples. The sequencing of the $180 \mathrm{~m}$ samples was performed at the Research and Testing Laboratory (Texas, USA) and the rest of the samples at the Institute of Biotechnology (Helsinki, Finland) using the FLX 454 Titanium platform (454 Life Sciences, Branford, CT, USA).

\subsection{Quality control, classification and phylogenetic analysis of sequences}

Sequences were analysed using Mothur (v. 1.32.1; Schloss et al., 2009) and QIIME programs (MacQIIME v. 1.7.0, Caporaso et al., 2010). The QIIME pipeline was used with $16 \mathrm{~S}$ rRNA gene sequences and Mothur with the functional gene sequences. In QIIME, sequences were compared against Greengenes representative OTU set version gg_13_8 with $97 \%$ similarity, and the taxonomy was assigned with RDP. With 16S rRNA sequences, the quality score window was set to 50 and sequences shorter than 360 and longer than 450 base pairs were discarded. The proximal primer sequences were allowed to have two or six nucleotide mismatches for bacterial and archaeal sequences, respectively. The high mismatch rate allowed for archaeal sequences was due to an extra guanine nucleotide in the primer sequence of the $500 \mathrm{~m}$ sample. Sequences of the functional genes representing sulfate reducers $(d s r B)$ and methanogens ( $m c r A$ ) were analysed with Mothur. Raw flowgrams were denoised with the PyroNoise algorithm to reduce PCR and sequencing noise in the data (Quince et al., 2009). All $d s r B$ sequences shorter than $200 \mathrm{bp}$ were discarded and no mismatches in the forward primer sequence were allowed. The length limit for $m c r A$ sequences was set to $100 \mathrm{bp}$ and four mismatches in primer sequence were allowed due to ambiguous bases in the primer sequence. The resulting sequences were further aligned with model alignments of $d s r B$ and $m c r A$ sequences from the Fungene repository (Fish et al., 2013) and sequences were assigned to operational taxonomic units (OTUs) with nearest-neighbour clustering method. Final phylogeny of the representative OTUs was done using the Geneious Pro software package, version 6.1.7 (Biomatters Inc., New Zealand) and blastn and blastx for comparison of the representative OTU sequences to NCBI's databases (Altschul et al., 1990). All sequence data were uploaded to the ENA database with accession numbers ERS846377-ERS846388 (bacteria), ERS846389- 
ERS846397 (archaea), ERS846399-ERS846407 (dsrB) and ERS846408-ERS846414 (mcrA).

\subsection{Ecological indices and statistical analyses}

Chao1 richness estimates were calculated for the bacterial and archaeal communities with $97 \%$ sequence similarity using the alpha.diversity.py command in QIIME. The estimates of diversity, richness and rarefaction were calculated from random subsample of 3030 sequences per sample for bacteria and 270 sequences per sample for archaea. The same $\alpha$-diversity estimates for $d s r B$ and $m c r A$ data sets were calculated in Mothur from subsamples of 115 and 1712 sequences, respectively. Due to the low number of $d s r B$ sequences (47) retrieved from the $180 \mathrm{~m}$ fracture, these data were not subsampled. The bacterial and archaeal OTUs with resolved taxonomy were compared to the hydrogeochemical data as well as to the lithology of each fracture zone. Canonical correspondence analysis was performed with Past 3 to the environmental metadata and taxonomical OTU matrix with all archaeal OTUs and bacterial OTUs with more than $0.1 \%$ abundance in the fracture communities (Hammer et al., 2001).

\subsection{Prediction of functionality and co-occurrence analysis}

De novo OTUs were removed from the 16S rRNA OTU taxonomy file (.biom-table) prior to uploading to the Galaxy pipeline for PICRUSt analysis (Goecks et al., 2010; Blankenberg et al., 2010; Giardine et al., 2005; Langille et al., 2013). PICRUSt compares 16S rRNA marker gene data to reference genomes and provides a prediction of the metagenome of a sample. Data in the biom file was normalized with the $16 \mathrm{~S}$ rRNA gene copy number. Prediction of the functionality of the metagenome of each sample was done by multiplying the normalized abundance of each OTU by each predicted functional feature abundance. A weighted nearest sequenced taxon index (NSTI) was calculated for all samples. The NSTI value describes the average branch length that separates each OTU in the sample from a reference genome, weighted by the abundance of that OTU in the sample. For example, the NSTI value of 0.03 means that the OTUs in the sample are on average $97 \%$ similar to the genomes in the database.

Co-occurrence of OTUs in total and active microbial communities of Outokumpu bedrock fractures was analysed with the otu.association command in Mothur. Based on pairwise Pearson correlations with significant $p$ value $(<0.01)$, visualization of the co-occurrence network was constructed using Fruchtermann-Feingold layout in the Gephi program (Bastian et al., 2009). The possible "keystone" OTUs were revealed with the betweenness centrality calculation and the connectivity of the network with the closeness centrality estimate (Brandes, 2001). Modular structure of the community was evaluated with the modularity index calculation (Blondel et al., 2008; Lambiotte et al., 2009).

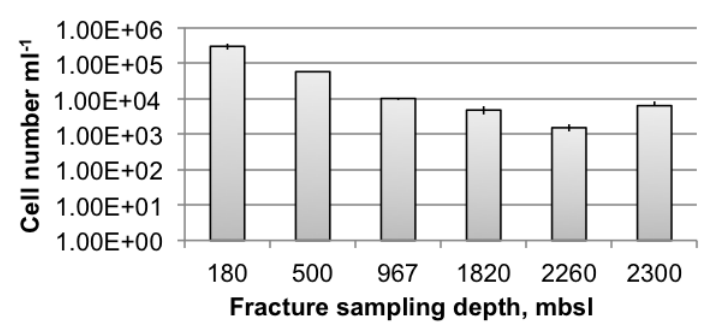

Figure 1. Total number of microbial cells in Outokumpu fracture fluids.

\section{Results}

\subsection{Microbial density in the fracture zones}

The total microbial cell numbers were highest in the $180 \mathrm{~m}$ fracture $\left(2.97 \times 10^{5}\right)$ and declined according to the depth (Fig. 1; Table 2). A similar trend was observed with the copy numbers of the bacterial 16S rRNA gene ranging from $5.13 \times 10^{6}$ in shallowest fracture to $9.00 \times 10^{2}$ in the deepest fracture. Archaeal 16S rRNA gene copy numbers varied more, but the highest number of archaeal 16S rRNA gene copies was detected from the fracture at $180 \mathrm{~m}$ depth $\left(6.24 \times 10^{3}\right.$; Table 2).

The number of $d s r B$ and $m c r A$ gene copies, used as an estimate for the amount of sulfate-reducing bacteria and methane-producing archaea, respectively, was assessed with quantitative PCR. The copy numbers were quantified also from RNA in order to estimate the activity of sulfate reduction and methanogenesis. The $d s r B$ copy numbers varied between 3 and $6 \times 10^{2}$ copies $\mathrm{mL}^{-1}$ in most fractures, with the exceptions of the 500 and $967 \mathrm{~m}$ fractures, where the $d s r B$ copy number was $7.4 \times 10^{3}$ and $1.5 \times 10^{1}$ copies $\mathrm{mL}^{-1}$, respectively (Supplement Table S1). As a proxy of active transcription of $d s r B$ genes, the number of mRNA transcripts was also quantified. The highest $d s r B$ gene transcription was observed at $1820 \mathrm{~m}$, where the number of $d s r B$ transcripts was more than $6.0 \times 10^{2}$ transcripts $\mathrm{mL}^{-1}$. All other fractures had below $1.0 \times 10^{2}$ transcripts $\mathrm{mL}^{-1}$. Methanogenesis marker gene copies were detected only from the upper three fractures $(180,500$ and $967 \mathrm{~m})$. The $m c r A$ gene copy numbers were just above the detection limit of the assay, i.e. less than $4.0 \times 10^{1}$ copies $\mathrm{mL}^{-1}$ in all. McrA gene transcripts were detected only from the $967 \mathrm{~m}$ fracture, where the copy number was just above $1.0 \times 10^{2} \mathrm{~mL}^{-1}$.

\subsection{The structure of the microbial communities and correlation to geochemistry}

The sequencing data acquired from DNA were used as a representation of the total microbial community present in the fracture fluid samples, whereas the microbial communities derived from RNA were used as a proxy of an active community. The microbial communities differed between the nu- 
Table 2. The total number of cells and the 16S rRNA gene copy numbers of microbial communities in six fractures of Outokumpu. Values are given in $\mathrm{mL}^{-1}$.

\begin{tabular}{lrr|rr|rr}
\hline \multirow{2}{*}{$\begin{array}{l}\text { Fracture depth } \\
(\mathrm{m})\end{array}$} & \multicolumn{2}{c}{ Total cell amount } & \multicolumn{2}{c|}{ Bacterial 16S rRNA gene } & \multicolumn{2}{c}{ Archaeal 16S rRNA gene } \\
& cell number & SEM $^{1}$ & copy number & SEM $^{1}$ & copy number & SEM $^{1}$ \\
\hline 180 & $2.97 \mathrm{E}+05$ & $6.25 \mathrm{E}+04$ & $5.13 \mathrm{E}+06$ & $1.49 \mathrm{E}+05$ & $6.24 \mathrm{E}+03$ & $1.25 \mathrm{E}+00$ \\
500 & $5.72 \mathrm{E}+04$ & $3.04 \mathrm{E}+03$ & $1.88 \mathrm{E}+06$ & $2.99 \mathrm{E}+05$ & $8.62 \mathrm{E}+01$ & $1.23 \mathrm{E}+00$ \\
967 & $1.00 \mathrm{E}+04$ & $8.91 \mathrm{E}+02$ & $1.26 \mathrm{E}+05$ & $2.15 \mathrm{E}+04$ & $4.90 \mathrm{E}+02$ & $1.24 \mathrm{E}+00$ \\
1820 & $4.74 \mathrm{E}+03$ & $1.17 \mathrm{E}+03$ & $9.05 \mathrm{E}+02$ & $2.29 \mathrm{E}+01$ & b.d. & n.a. \\
2260 & $1.51 \mathrm{E}+03$ & $3.52 \mathrm{E}+02$ & $9.01 \mathrm{E}+02$ & $3.72 \mathrm{E}+01$ & $2.32 \mathrm{E}+01$ & $1.07 \mathrm{E}+00$ \\
2300 & $6.30 \mathrm{E}+03$ & $1.89 \mathrm{E}+03$ & $9.00 \mathrm{E}+02$ & $2.07 \mathrm{E}+01$ & b.d. & n.a. \\
\hline
\end{tabular}

${ }^{1}$ SEM: standard error of mean; b.d.: below detection limit; n.a.: not available.

DNA
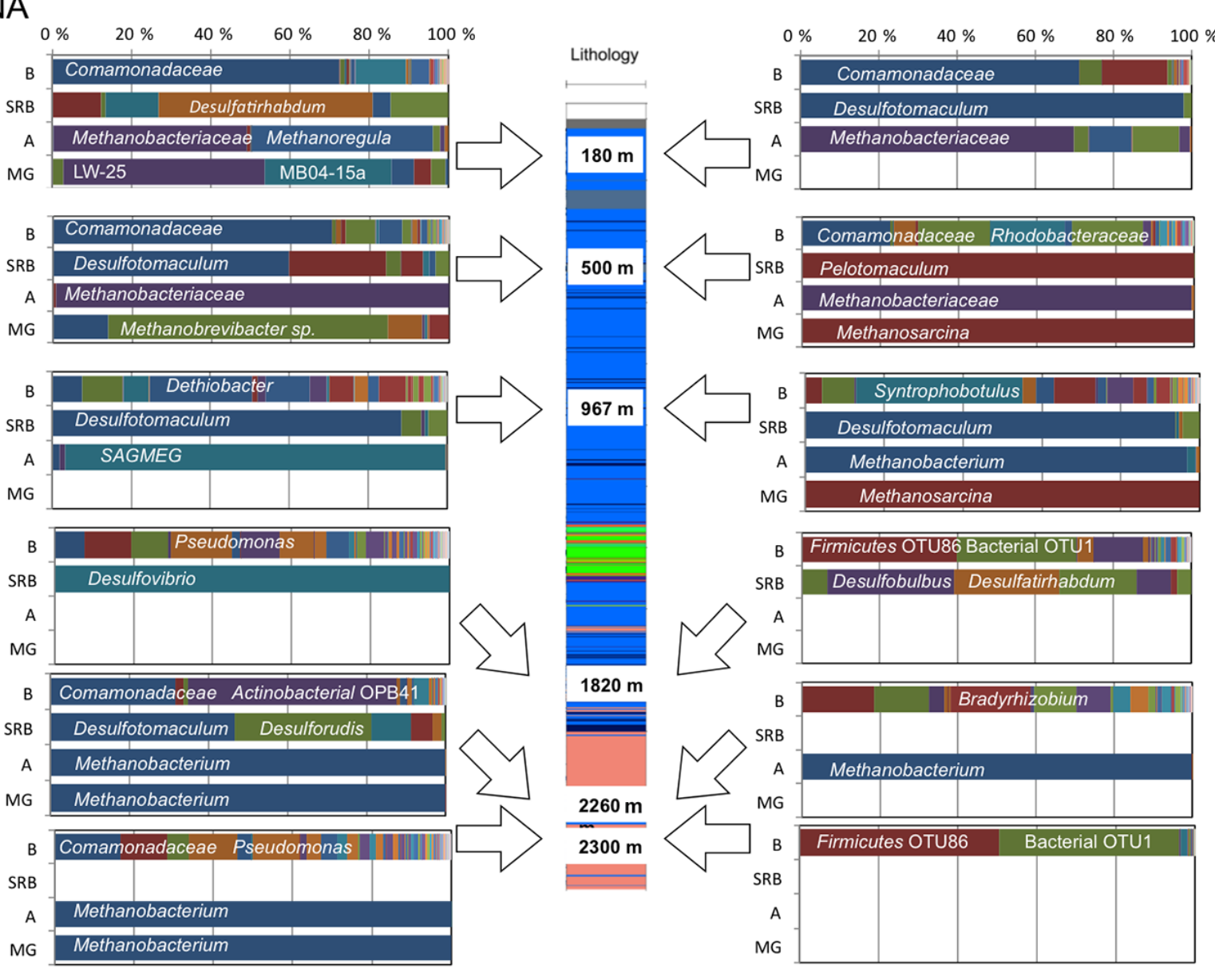

Figure 2. Microbial community structure at six different fractures in Outokumpu Precambrian crystalline bedrock. In the centre is a schematic presentation of the Outokumpu Deep Drill hole lithology (blue mica schist, green ophiolitic rocks, pink pegmatitic granite) with arrows pointing to the depths of the fractures studied. The composition of the total communities on the left and the active communities on the right side. The taxonomic classification of only the most abundant OTUs is shown. B: bacteria; SRB: sulfate-reducing bacteria; A: archaea; MG: methanogens.

cleic acid fractions as well as the sampling depth (Fig. 2). Pyrosequencing of the total and active bacterial communities based on the 16S rRNA gene resulted to 268 identified OTUs representing a total of 157 families in six fractures analysed
(Table S2). Sulfate-reducing communities (based on the $d s r B$ gene) were successfully sequenced from all fracture fluid samples except the active community in the $2260 \mathrm{~m}$ fracture and total and active communities in $2300 \mathrm{~m}$. The archaeal 
communities were overall less diverse than the bacterial communities. Archaeal sequences (16S rRNA gene) were retrieved from all fractures except the one at $1820 \mathrm{~m}$. Only 17 different OTUs could be divided into 11 families (Table S3). Total methanogen communities were detected from 180, 500, 2260 and $2300 \mathrm{~m}$ fractures and active methanogen communities from 500 and $967 \mathrm{~m}$ fractures.

Primers used in the archaeal nested PCR are reported to have frequent mismatch rate to some archaeal groups, such as SAGMEG (South-African Gold Mine Miscellaneous Euryarchaeal Group), leading to underestimation of these groups in the community structure (Teske and Sørenson, 2008; Wang and Qian, 2009). Using the Ribosomal Database Project's probe match platform, we detected that although the overall coverage of the used archaeal primers in this study ranged from 33 to $31 \%$ (first and second PCR, respectively), the coverage of the primers for phylum Thermococci, to which SAGMEG archaea belong, was much higher, 81$91 \%$.

\subsubsection{The $180 \mathrm{~m}$ fracture}

The bacterial communities in the upmost fracture zone analysed in this study were dominated by OTUs resembling $\mathrm{Co}$ mamonadaceae (Fig. 2). This $\beta$-proteobacterial family constituted over $70 \%$ of the OTUs in total and active communities in the $180 \mathrm{~m}$ fracture (Table S2). The estimated richness of the community was $69 \%$ of the observed OTUs of the $180 \mathrm{~m}$ bacterial communities (Table S4a). Desulfatirhabdum (54\% relative abundance) and Desulfotomaculum (98\% relative abundance) were most abundant in total and active sulfate-reducing communities, respectively (Fig. 2). The archaeal community in the fracture zone at $180 \mathrm{~m}$ was dominated by OTUs affiliated with Methanobacteriaceae and Methanoregula, while Methanosarcina and methylotrophic Methanolobus OTUs represented minor groups (Table S3). This depth hosted the most diverse archaeal communities (the Shannon diversity index H' 2.4 and 2.1 for total and active archaeal communities, respectively; Table S4b). Similarly, the methanogen community was the most diverse at this fracture, and the dominant groups were similar to unclassified, uncultured methanogen sequences retrieved from wetland soil (LW-25) and acidic peat bog (MB04-15a).

\subsubsection{The $500 \mathrm{~m}$ fracture}

The total bacterial community in the $500 \mathrm{~m}$ fracture was dominated by Comamonadaceae (70\%; Fig. 2, Table S2). The dominant OTUs in active bacterial community affiliated with $\alpha$-proteobacterial order Rhodobacterales with $38 \%$ relative abundance; otherwise, this community comprised OTUs affiliating with Comamonadaceae (23\%), Dietzia (23\%) and Pseudomonas (6\%). The number of observed OTUs captured $77-86 \%$ richness of the communities according to the Chaol estimate at this depth (Ta- ble S4a). Desulfotomaculum and Pelotomaculum-affiliating OTUs were the most dominant sulfate reducers in this fracture (Fig. 2). The total and active archaeal communities comprised almost solely of methanogenic Methanobacteriaceae, while Methanobrevibacter and Methanosarcina dominated the communities detected with the methanogenspecific marker gene ( $m c r A$; Fig. 2).

\subsubsection{The $967 \mathrm{~m}$ fracture}

The total bacterial community in $967 \mathrm{~m}$ fracture zone comprised of Natrananaerobiales, Clostridiales and other Firmicutes in addition to the mollicute Acholeplasma. In the active bacterial community, peptococcal Syntrophobotulus dominated and otherwise the community resembled the total community (Fig. 2). The observed richness was 84 or $88 \%$ of the estimated richness of the total and active communities, respectively (Table S4a). Based on the Shannon diversity index $\mathrm{H}^{\prime}$ (2.3) the total archaeal community in the $967 \mathrm{~m}$ fracture was among the most diverse of the archaeal communities. It was dominated by OTUs affiliating with SAGMEG-1 Euryarchaeota. In the active archaeal community in this fracture Methanobacteriaceae dominated and SAGMEG OTUs represented only a minority of the OTUs. Methanosarcina dominated the active methanogen community in the $967 \mathrm{~m}$ fracture (Fig. 2).

\subsubsection{The $1820 \mathrm{~m}$ fracture}

The number of observed bacterial OTUs was among the highest in both total and active bacterial communities in the fracture zone at $1820 \mathrm{~m}$. Pseudomonadales (29\% relative abundance), Burkholderiales (22\%) with Comamonadaceae and Oxalobacteraceae, and Clostridiales (13\%) comprised mainly of Dethiosulfatibacter and other Firmicutes with unresolved phylogeny dominated the total community in this fracture zone. In the active community, OTU 86 belonging to Firmicutes was dominant, with $39 \%$ relative abundance (Fig. 2). The sequenced communities at this depth were estimated to have captured in average $80 \%$ of the richness of the total communities (Table S4a). The total SRB community in this fracture was entirely composed of Desulfovibrioaffiliating OTU. The estimated diversity was low because only 115 sequences were retained. On the other hand, the active SRB community was diverse, with OTUs affiliating with Desulfatirhabdum, Desulfobulbus and Desulfoarculus. Amplification of archaeal and methanogen communities was not successful from this fracture, indicating low abundance of these groups.

\subsubsection{The $2260 \mathrm{~m}$ fracture}

The fracture at $2260 \mathrm{~m}$ hosted a bacterial community mainly comprising of actinobacterial OBP41 class (53\% relative abundance) and Burkholderiales (34\%; Fig. 2). The active community in this fracture had the highest number of ob- 
served OTUs of the whole data set and best success in capturing the richness $(91 \%)$ of the community. OTUs belonging to $\alpha$-proteobacterial Bradyrhizobium (20\%) and Rickettsiales $(11 \%)$ in addition to Firmicutes and Actinobacteria dominated this active community. Desulfotomaculum and Desulforudis-affiliating OTUs dominated the total SRB community at this fracture and Methanobacterium dominated both archaeal and methanogen communities (Fig. 2).

\subsubsection{The $2300 \mathrm{~m}$ fracture}

The most frequent OTUs in the bacterial communities in the fracture zone at $2300 \mathrm{~m}$ represented Burkholderiales (31\% of the OTUs) and Pseudomonadales (25\%) such as Moraxellaceae and Pseudomonadaceae. In addition, OTUs belonging to other Firmicutes, Clostridiales, Actinomycetales and Natranaerobiales were detected (Fig. 2). The sequenced DNA community covered $86 \%$ of the estimated richness. The active community of this fracture mainly composed of unclassifiable OTUs: only $4 \%$ of the community could be determined to more specifically than to phylum level, while half of the community could be determined only to phylum level (Firmicutes), leaving the rest of the community, $46 \%$, unresolved. This also reflected the richness and coverage indicator values: only $51 \%$ of the richness was captured and the coverage was barely half $(51 \%)$ of the total abundance of the community.

Sulfate reducers were not detected at this depth, and Methanobacterium dominated the total archaeal and methanogen communities.

\subsubsection{The core microbial community in Outokumpu bedrock fractures}

Only a few OTUs that were present in all communities constituted the core community in the Outokumpu deep bedrock. Pseudomonas and Dethiosulfatibacter in addition to two OTUs with uncertain taxonomic classification (Firmicutes OTU 86 and bacterial OTU1) were detected in all total and active bacterial communities. When observing only the total bacterial communities, most abundant members of the core community were Comamonadaceae, Dethiobacter and Pseudomonas.

\subsubsection{The relationship of the microbial community structure to geochemistry}

Microbial OTUs formed three loose clusters in canonical correspondence analysis based on the depth where fracture fluid samples were retrieved (Fig. 3). A cluster of bacterial OTUs belonging to orders Burkholderiales and Rhodobacterales plotted near 180 and $500 \mathrm{~m}$ depths and correlated with biotite gneiss and concentration of its major elemental components - iron and magnesium. Microbial OTUs affiliating with the most abundant groups in the $967 \mathrm{~m}$ fracture (Peptococcaceae, Anaerobrancaceae, Thermoanaerobacterales, SAG-
MEG archaea) grouped loosely around the $967 \mathrm{~m}$ depth, with sulfur concentration pointing to this ordination. The depths of 1820 and $2300 \mathrm{~m}$ correlated with sulfide concentration and defining rock types were black schist and pegmatitic granite. Clostridial Dethiosulfatibacter and other Firmicutesaffiliating OTUs in addition to several Burkholderialesaffiliating OTUs clustered close to these depths.

\subsection{The functionality estimation of the microbial communities}

The physiology of the members of the microbial communities was estimated from classified OTUs based on the prevalent physiology of the cultured representatives of each OTU at family level according to the Prokaryotes handbook (Dworkin et al., 2006; Fig. 4). Bacterial physiotypes with capacity to use versatile metabolic pathways for carbon assimilation and energy production were characteristic in the fracture communities at shallower depths (180 and $500 \mathrm{~m})$, while lithotrophic bacterial physiotypes are more frequently detected in 967 and $1820 \mathrm{~m}$ fractures. Overall, physiotypes with unknown metabolism became more frequent in the communities at fractures located deeper in the bedrock due to the lack of exact taxonomic classification of the OTUs detected in these fractures (Fig. 4a). In the archaeal communities the most dominant archaeal physiotype was hydrogenotrophic methanogenesis, except in the $967 \mathrm{~m}$ fracture (Fig. 4b). The total archaeal community in this fracture was dominated by SAGMEG - affiliating OTUs with undetermined physiology.

\subsubsection{Predicted bacterial metagenomes}

The metagenomes of the microbial communities of different fracture zones representing six different biotopes were predicted from the 16S rRNA gene sequences, i.e. from the different OTUs with resolved taxonomy. In order to evaluate the accuracy of the prediction of metagenomes, nearest sequenced taxon index (NSTI) was calculated for each sample (Table S5). The NSTIs varied between the bacterial communities, from 0.07 (the communities in the 1820 and $2300 \mathrm{~m}$ fractures) to 0.30 (the community in the $2260 \mathrm{~m}$ fracture). The archaeal communities represented NSTIs from 0.04 to 0.07 , with the exception of the total community in $967 \mathrm{~m}$ fracture, of which the NSTI was 0.29 . Overall, the predicted metagenomes of the total communities did not vary greatly from the active community metagenomes. Top-level functionality estimates revealed differences between bacterial and archaeal communities. The average values for cellular processes and environmental information processing were more abundant in the predicted bacterial metagenomes than in the archaeal metagenomes. In contrast, genetic information processing and unknown features were more abundant in the predicted archaeal metagenomes (Fig. 5).

The most abundant group of bacterial predicted on the basis of PICRUSt analysis were those involved in amino 


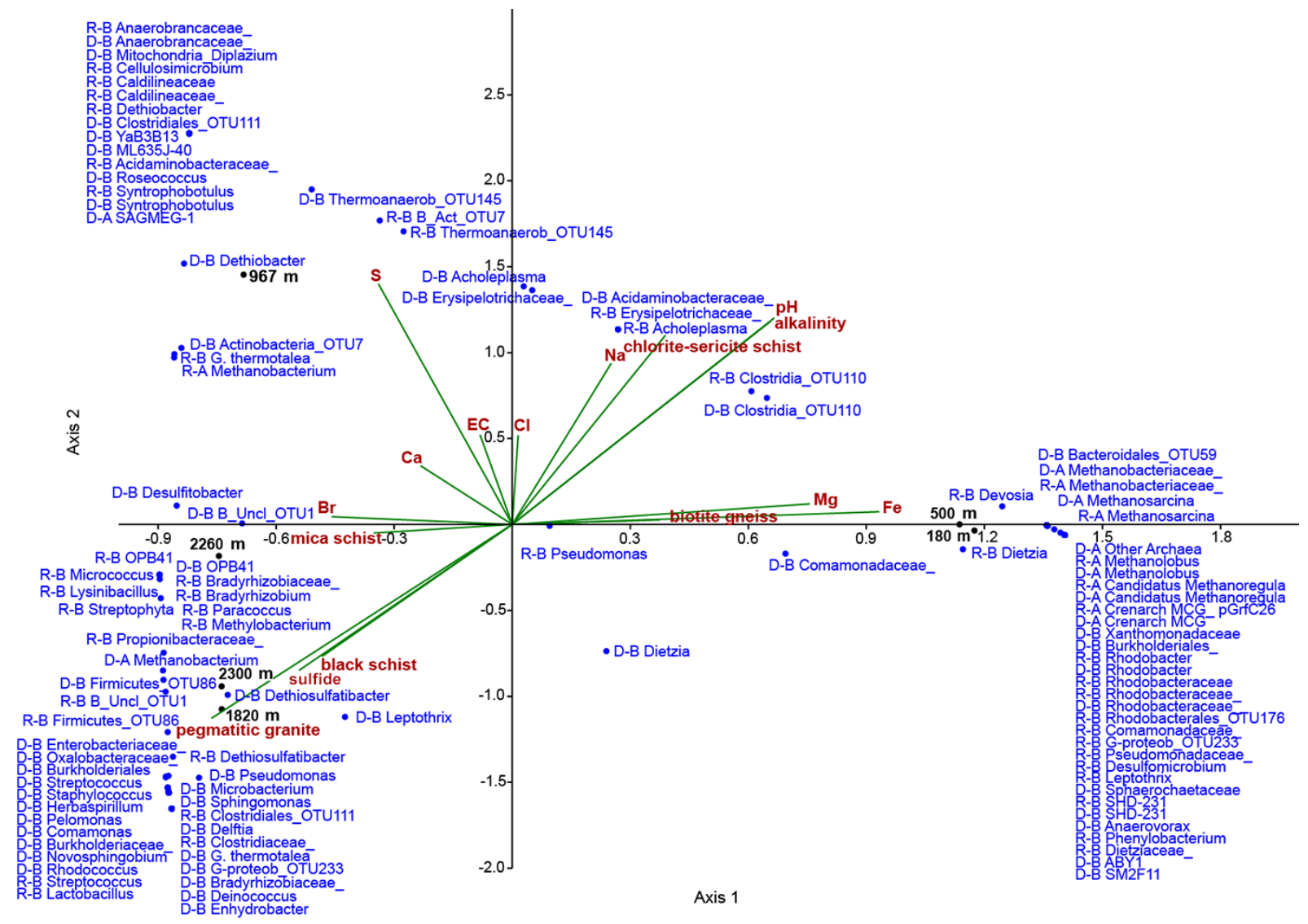

Figure 3. Canonical correspondence plot of the microbial OTUs (blue, with letters before the OTU name denoting the origin and the domain, i.e. D: derived from DNA; R: derived from RNA; B: bacteria; A: archaea), depths (black) and the geochemical parameters (red). The horizontal axis explains the $35 \%$ of the variance of the data with statistical significance $(p<0.01)$, while the vertical axis explains $27 \%$ of the variance of the data $(p=0.11)$.

acid metabolism (21-22\% of all metabolism genes), carbohydrate metabolism (19-21\%) and energy metabolism (11$13 \%$ of all genes involved in metabolism; Table $3 a)$. The predicted bacterial metagenomes differed mostly between $180 \mathrm{~m}$ and other fractures. In all fractures, the most abundant amino acid metabolism genes were amino acid-related enzymes and arginine and proline metabolism genes (1115 and $11-13 \%$, respectively; Table S6a). Gene predictions on carbohydrate utilization revealed a highly similar pattern in all other fracture communities than those at $180 \mathrm{~m} \mathrm{(Ta-}$ ble S6a). Amino sugar metabolism genes were more abundant in the $180 \mathrm{~m}$, while in other fractures propanoate and butanoate metabolism genes were dominant. The most abundant energy metabolism genes were involved in oxidative phosphorylation in the predicted metagenomes of the bacterial communities (22-26\% in total bacterial communities, and $20-28 \%$ in active communities; Table S6a). Genes involved in carbon fixation pathways in prokaryotes were almost as common, in addition to methane metabolism genes.

\subsubsection{Predicted archaeal metagenomes}

Similar to bacteria, half of the genes in the predicted archaeal metagenomes of each fracture zone were involved in metabolism (Fig. 5b). Energy metabolism genes were most common (18-25\%) in addition to amino acid metabolism and carbohydrate metabolism genes (21-25 and $17-20 \%$, respectively; Table $3 \mathrm{~b}$ ). The predicted metagenome of the total archaeal community in the $967 \mathrm{~m}$ fracture zone had the highest abundance of amino acid metabolism genes ( $25 \%$ of all metabolism genes) and the lowest abundance of energy metabolism genes $(18 \%)$ and thus differed from the community metagenome derived from RNA in the same fracture. Otherwise, the predicted metabolism genes were similar in the different archaeal communities in the fracture zones. The predicted metagenome of the total archaeal community of the $967 \mathrm{~m}$ fracture also differed in predicted amino acid usage, carbohydrate metabolism and in the energy metabolism gene predictions. As expected, genes representing methane metabolism were the most dominant in all archaeal communities (Table S6b). 
Table 3. The most abundant metabolism-related (a) bacterial and (b) archaeal genes in the predicted metagenomes.

\begin{tabular}{|c|c|c|c|c|c|c|c|c|c|c|c|c|}
\hline \multirow[t]{2}{*}{ (a) } & \multicolumn{2}{|c|}{$180 \mathrm{~m}$} & \multicolumn{2}{|c|}{$500 \mathrm{~m}$} & \multicolumn{2}{|c|}{$967 \mathrm{~m}$} & \multicolumn{2}{|c|}{$1820 \mathrm{~m}$} & \multicolumn{2}{|c|}{$2260 \mathrm{~m}$} & \multicolumn{2}{|c|}{$2300 \mathrm{~m}$} \\
\hline & DNA & RNA & DNA & RNA & DNA & RNA & DNA & RNA & DNA & RNA & DNA & RNA \\
\hline Carbohydrate metabolism & $19 \%$ & $21 \%$ & $20 \%$ & $19 \%$ & $20 \%$ & $19 \%$ & $19 \%$ & $20 \%$ & $21 \%$ & $19 \%$ & $19 \%$ & $19 \%$ \\
\hline Amino acid metabolism & $21 \%$ & $21 \%$ & $22 \%$ & $23 \%$ & $22 \%$ & $22 \%$ & $21 \%$ & $22 \%$ & $21 \%$ & $21 \%$ & $22 \%$ & $21 \%$ \\
\hline Energy metabolism & $13 \%$ & $13 \%$ & $12 \%$ & $11 \%$ & $11 \%$ & $13 \%$ & $11 \%$ & $12 \%$ & $13 \%$ & $13 \%$ & $11 \%$ & $11 \%$ \\
\hline Metabolism of cofactors and vitamins & $9 \%$ & $0 \%$ & $9 \%$ & $9 \%$ & $8 \%$ & $10 \%$ & $8 \%$ & $8 \%$ & $9 \%$ & $8 \%$ & $8 \%$ & $9 \%$ \\
\hline Lipid metabolism & $6 \%$ & $0 \%$ & $7 \%$ & $8 \%$ & $8 \%$ & $7 \%$ & $8 \%$ & $8 \%$ & $7 \%$ & $7 \%$ & $8 \%$ & $7 \%$ \\
\hline Nucleotide metabolism & $8 \%$ & $0 \%$ & $7 \%$ & $6 \%$ & $7 \%$ & $8 \%$ & $6 \%$ & $7 \%$ & $7 \%$ & $7 \%$ & $6 \%$ & $8 \%$ \\
\hline Xenobiotics biodegradation and metabolism & $4 \%$ & $0 \%$ & $7 \%$ & $8 \%$ & $7 \%$ & $6 \%$ & $9 \%$ & $6 \%$ & $7 \%$ & $9 \%$ & $9 \%$ & $7 \%$ \\
\hline Metabolism of terpenoids and polyketides & $4 \%$ & $0 \%$ & $4 \%$ & $5 \%$ & $5 \%$ & $4 \%$ & $4 \%$ & $4 \%$ & $5 \%$ & $5 \%$ & $4 \%$ & $4 \%$ \\
\hline Metabolism of other amino acids & $4 \%$ & $0 \%$ & $4 \%$ & $4 \%$ & $4 \%$ & $3 \%$ & $4 \%$ & $4 \%$ & $4 \%$ & $4 \%$ & $4 \%$ & $4 \%$ \\
\hline Enzyme families & $4 \%$ & $0 \%$ & $3 \%$ & $3 \%$ & $4 \%$ & $4 \%$ & $4 \%$ & $4 \%$ & $3 \%$ & $3 \%$ & $4 \%$ & $4 \%$ \\
\hline Glycan biosynthesis and metabolism & $7 \%$ & $0 \%$ & $3 \%$ & $3 \%$ & $4 \%$ & $4 \%$ & $4 \%$ & $3 \%$ & $3 \%$ & $3 \%$ & $4 \%$ & $4 \%$ \\
\hline Biosynthesis of other secondary metabolites & $2 \%$ & $0 \%$ & $2 \%$ & $2 \%$ & $2 \%$ & $2 \%$ & $1 \%$ & $1 \%$ & $1 \%$ & $2 \%$ & $2 \%$ & $1 \%$ \\
\hline \multirow[t]{2}{*}{ (b) } & \multicolumn{2}{|c|}{$180 \mathrm{~m}$} & \multicolumn{2}{|c|}{$500 \mathrm{~m}$} & \multicolumn{2}{|c|}{$967 \mathrm{~m}$} & \multicolumn{2}{|c|}{$1820 \mathrm{~m}$} & \multicolumn{2}{|c|}{$2260 \mathrm{~m}$} & \multicolumn{2}{|c|}{$2300 \mathrm{~m}$} \\
\hline & DNA & RNA & DNA & RNA & DNA & RNA & DNA & RNA & DNA & RNA & DNA & RNA \\
\hline Energy metabolism & $23 \%$ & $23 \%$ & $25 \%$ & $25 \%$ & $18 \%$ & $24 \%$ & n.d. & n.d. & $24 \%$ & $24 \%$ & $24 \%$ & n.d. \\
\hline Amino acid metabolism & $21 \%$ & $21 \%$ & $21 \%$ & $21 \%$ & $25 \%$ & $22 \%$ & & & $22 \%$ & $22 \%$ & $22 \%$ & \\
\hline Carbohydrate metabolism & $18 \%$ & $20 \%$ & $17 \%$ & $17 \%$ & $19 \%$ & $17 \%$ & & & $17 \%$ & $17 \%$ & $17 \%$ & \\
\hline Nucleotide metabolism & $11 \%$ & $10 \%$ & $11 \%$ & $11 \%$ & $13 \%$ & $11 \%$ & & & $11 \%$ & $11 \%$ & $11 \%$ & \\
\hline Metabolism of cofactors and vitamins & $10 \%$ & $10 \%$ & $11 \%$ & $11 \%$ & $10 \%$ & $10 \%$ & & & $10 \%$ & $10 \%$ & $10 \%$ & \\
\hline Xenobiotics biodegradation and metabolism & $3 \%$ & $4 \%$ & $3 \%$ & $3 \%$ & $2 \%$ & $3 \%$ & & & $3 \%$ & $3 \%$ & $3 \%$ & \\
\hline Enzyme Families & $3 \%$ & $3 \%$ & $3 \%$ & $3 \%$ & $3 \%$ & $3 \%$ & & & $3 \%$ & $3 \%$ & $3 \%$ & \\
\hline Metabolism of terpenoids and polyketides & $3 \%$ & $3 \%$ & $3 \%$ & $3 \%$ & $3 \%$ & $3 \%$ & & & $3 \%$ & $3 \%$ & $3 \%$ & \\
\hline Glycan biosynthesis and metabolism & $2 \%$ & $2 \%$ & $3 \%$ & $3 \%$ & $2 \%$ & $2 \%$ & & & $2 \%$ & $2 \%$ & $2 \%$ & \\
\hline Biosynthesis of other secondary metabolites & $2 \%$ & $2 \%$ & $2 \%$ & $2 \%$ & $2 \%$ & $2 \%$ & & & $2 \%$ & $2 \%$ & $2 \%$ & \\
\hline Lipid metabolism & $2 \%$ & $1 \%$ & $1 \%$ & $1 \%$ & $2 \%$ & $1 \%$ & & & $1 \%$ & $1 \%$ & $1 \%$ & \\
\hline Metabolism of other amino acids & $1 \%$ & $1 \%$ & $1 \%$ & $1 \%$ & $1 \%$ & $1 \%$ & & & $1 \%$ & $1 \%$ & $1 \%$ & \\
\hline
\end{tabular}

n.d.: not detected

Table 4. The "keystone genera" of the total microbial communities in Outokumpu fractures.

\begin{tabular}{lrrrlr}
\hline Keystone OTUs & $\begin{array}{r}\text { Closeness } \\
\text { centrality }\end{array}$ & $\begin{array}{r}\text { Betweenness } \\
\text { centrality }\end{array}$ & Degree & $\begin{array}{l}\text { Family } \\
\text { abundance }\end{array}$ & Relative \\
\hline Other Burkholderiaceae & 2.0 & 394 & 41 & Burkholderiaceae & $1 \%$ \\
Desulfitobacter & 2.4 & 302 & 4 & Peptococcaceae & $6 \%$ \\
Other Clostridiaceae & 1.7 & 302 & 20 & Clostridiaceae & $2 \%$ \\
Dethiobacter & 2.4 & 302 & 26 & Anaerobrancaceae & $25 \%$ \\
Herbaspirillum & 1.8 & 248 & 48 & Oxalobacteraceae & $6 \%$ \\
Pelomonas & 1.8 & 218 & 41 & Comamonadaceae & $72 \%$ \\
Novosphingobium & 1.1 & 162 & 46 & Sphingomonadaceae & $2 \%$ \\
Comamonas & 1.8 & 151 & 29 & Comamonadaceae & $72 \%$ \\
\hline Average & 1.4 & 21 & 25 & & \\
\hline
\end{tabular}

${ }^{1}$ Highest relative abundance in the family level in the community.

\subsection{Co-occurrence of microbial OTUs in deep crystalline bedrock}

From all detected microbial OTUs in deep crystalline fractures, only $15 \%$ showed positive correlation $(r>0.8)$ with other members of the microbial communities. Only three significantly negative correlations ( $p \leq 0.01, r>0.8$ ) were detected among the total microbial communities and none in the active communities. The network analysis of the total microbial community divided significantly correlating OTUs into eight modules with number of nodes ranging from 4 to 41 (Fig. 6). The closeness of centrality (CC) values varied only slightly between most of the OTUs indicating that the network had high connectance between different members (variance 0.5; Table 4). The "keystone" OTUs were detected based on their above 300 betweenness of centrality 
Table 5. The "keystone genera" of the active microbial communities in Outokumpu fractures.

\begin{tabular}{lrrrlr}
\hline Keystone OTUs & $\begin{array}{r}\text { Closeness } \\
\text { centrality }\end{array}$ & $\begin{array}{r}\text { Betweenness } \\
\text { centrality }\end{array}$ & Degree & $\begin{array}{l}\text { Family } \\
\text { abundance }\end{array}$ \\
\hline Curvibacter & 1.8 & 797 & 41 & Comamonadaceae $^{\text {Relative }}$ & $71 \%$ \\
Comamonas & 1.8 & 476 & 4 & Comamonadaceae & $71 \%$ \\
Sphingomonas & 1.7 & 474 & 20 & Sphingomonadaceae & $0.1 \%$ \\
Bacilli OTU87 & 1.1 & 294 & 26 & Bacilli $^{2}$ & $1 \%$ \\
Flavobacterium & 1.8 & 276 & 48 & Flavobacteriaceae & $<0.1 \%$ \\
Williamsia & 1.1 & 256 & 41 & Williamsiaceae & $<0.1 \%$ \\
Staphylococcus & 2.5 & 189 & 46 & Staphylococcaceae & $1 \%$ \\
Oxalobacteraceae & 1.8 & 172 & 29 & Oxalobacteraceae & $0.3 \%$ \\
Herbaspirillum & 1.9 & 155 & 57 & Oxalobacteraceae & $0.3 \%$ \\
\hline Average & 1.3 & 21 & 37 & & \\
\hline
\end{tabular}

${ }^{1}$ Highest relative abundance in the family level in the community. ${ }^{2}$ Only identified to class level.
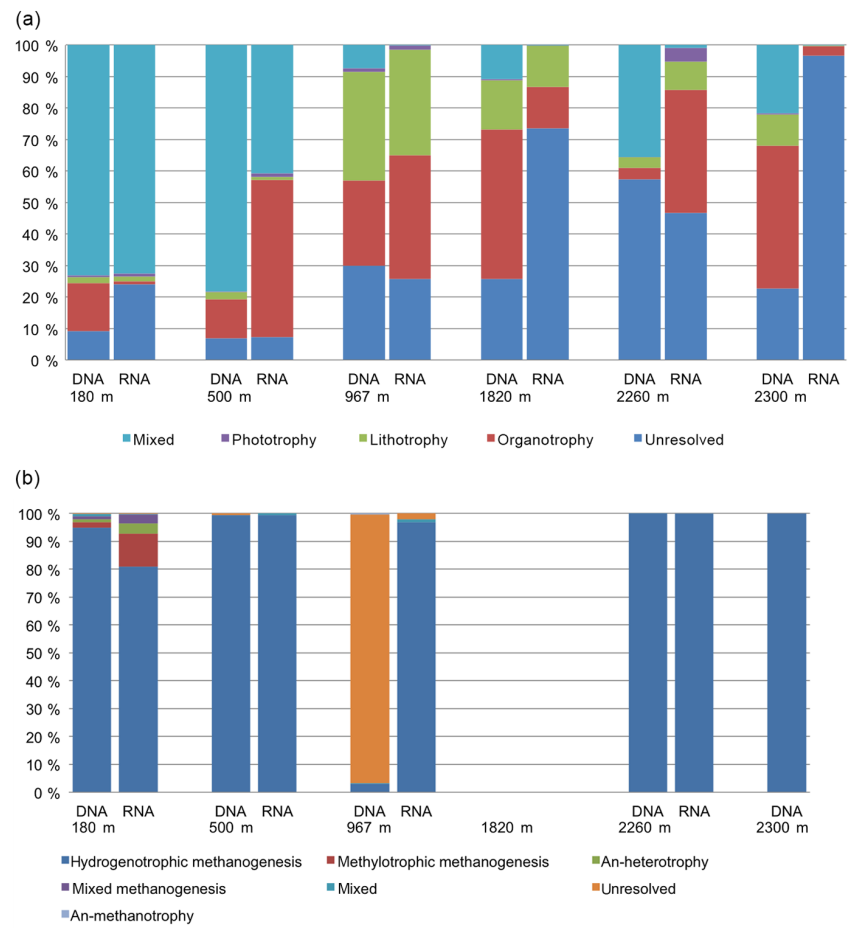

Figure 4. Binned (a) bacterial and (b) archaeal physiotypes according to the predominant metabolism of OTUs in the family level.

(BC) value, and these belonged to the Burkholderiaceaelike OTU, Desulfitobacter and the Clostridiaceae-affiliating OTU, all of which had relatively low abundance (0-3\%) in the communities, in addition to Dethiobacter, with 0-5\% relative abundance in other total bacterial communities except in the $967 \mathrm{~m}$ fracture, in which the relative abundance of this OTU in the total bacterial community was higher, $25 \%$ (Figs. 2a and 6). The most connected OTUs in the network belonged to Rhodococcus and Herbaspirillum (48 connections each) in addition to OTUs resembling Reni- bacterium, Gemellaceae, Trabulsiella and Novosphingobium (46-47 connections each). The positively correlating OTUs of the active microbial community divided into 8 clusters with number of nodes ranging from 2 to 64 (Fig. 7). The active community network also had small variation in the $\mathrm{CC}$ values (variance 0.3). The "keystone" genera of the active microbial community network were Comamonas, Curvibacter and Sphingomonas, with BC values above 470 each. Comamonadaceae-affiliating OTU was determined to be part of the core community in this Fennoscandian deep subsurface site, as it was frequently found in all depths with relatively high abundance ranging from 7 to $72 \%$ of the total community. Curvibacter and Sphingomonas were both present in the active communities, but with a very low relative abundance.

\section{Discussion}

The bacterial community structure in the groundwater of Outokumpu fracture zones varies between the different depths. In addition, the structure of the total and active communities differs within the fracture zones. The core bacterial community of deep crystalline bedrock fracture fluids in Outokumpu was composed of few OTUs found in all microbial communities in the fractures. Most abundant of these were Comamonadaceae-, Firmicutes-, Anaerobrancaceaeand Pseudomonadaceae-affiliating OTUs. However, the majority of the bacterial OTUs discovered in this study could be regarded as members of the so-called "rare biosphere" with their relatively low abundance and uneven distribution throughout the fracture zones (Sogin et al., 2006).

A keystone species has greater impact on its community or living environment than would be expected from its relative abundance or total biomass (Paine 1995). Steele et al. (2011) suggested that the highly connected nodes in cooccurrence network would be analogous to microbial "key- 

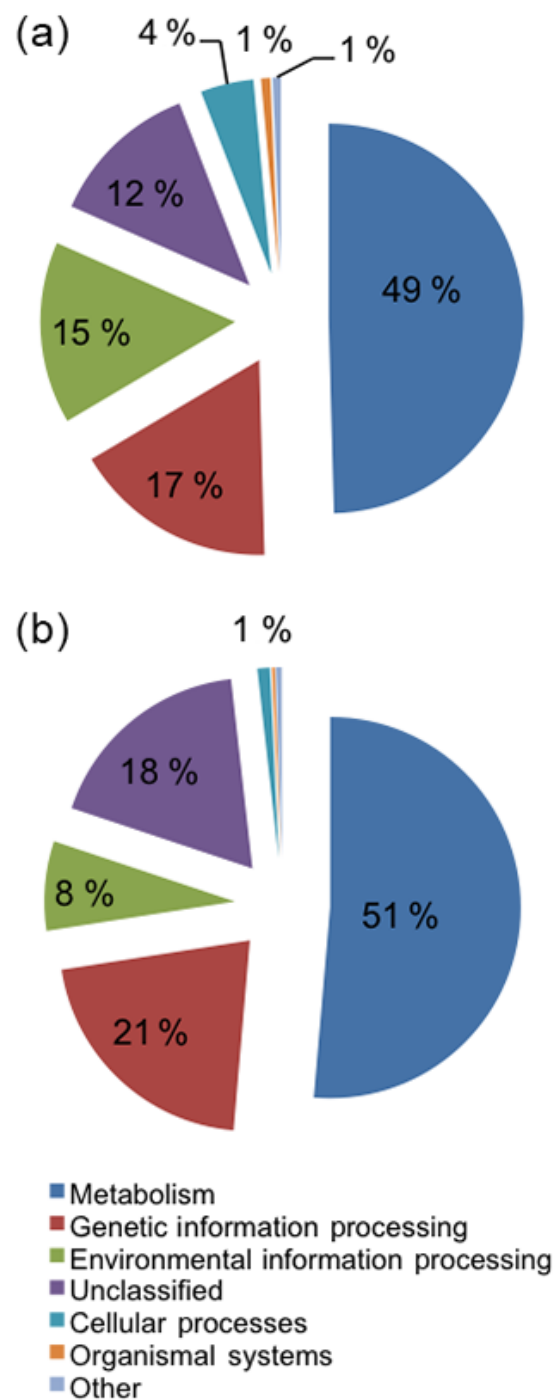

Figure 5. The average predicted functionality of all (a) bacterial and (b) archaeal metagenomes reconstructed from 16S rRNA gene sequences.

stone species". The most connected nodes of both the active and the total microbial community were representatives of Burkholderiales (e.g. Comamonas, Curvibacter, Oxalobacter, Herbaspirillum, Pelomonas, Cupriavidus), thus representing the possible "keystone species" of deep bedrock fracture fluid communities in Outokumpu. In addition, some clostridial phylotypes were among the highly connected nodes. Several of these "keystone" genera detected with the co-occurrence networks were members of the rare biosphere, thus providing further evidence for the significance of the less abundant microorganisms for the whole community (Sogin et al., 2006; Brown et al., 2009). Hence, we propose that these have a major role in the functionality of the network. The species belonging to Burkholderiales are most likely involved in hydrogen oxidation in the deep subsurface and thus are the potential primary producers in this oligotrophic environment. Clostridial species, on the other hand, could be occupying the niche for heterotrophic carbon assimilation, possibly providing $\mathrm{H}_{2}$ produced in fermentation processes. Burkholderiales and clostridial species have been found in other serpentinite-hosted deep subsurface aquifers (Brazelton et al., 2012; Tiago et al., 2013). These studies have suggested that Burkholderiales and clostridial species play a significant role in carbon and energy exchange between one another and other bacterial groups in these environments. The metabolic flexibility of Burkholderiales species, for example the ability to use both autotrophic and heterotrophic carbon fixation mechanisms is beneficial in isolated deep biosphere environments where concentrations of different carbon substrates fluctuate over time (Moser et al., 2005; Magnabosco et al., 2016).

One of the most connected nodes in active microbial community was Staphylococcus. We assume that this can be explained by contamination. Staphylococci are common in the human body, and while the number of sequences affiliating with Staphylococcus was low, they were discovered in all samples. However, we cannot ascertain the physiology of an OTU from its taxonomic affiliation and these Staphylococcus-like OTUs might be true members of the deep biosphere.

\subsection{Serpentinization as a source for energy in Outokumpu}

Hydrogen oxidizing, facultatively chemolithotrophic members of the Comamonadaceae family were dominant in the 180 and $500 \mathrm{~m}$ fracture zone communities. These microbes are commonly found in hydrogen-enriched subsurface environments. These include findings of Ralstonia and $\mathrm{Hy}$ drogenophaga in Lost City Hydrothermal Field and Tablelands Ophiolite serpentinite springs, respectively (Brazelton et al., 2012, 2013). Likewise, Comamonadaceae-affiliating and clostridial sequences formed the majority of the bacterial community in serpentinization-driven subsurface aquifer in Portugal (Tiago and Veríssimo, 2013). Comamonadaceae were also dominant in the drill hole water communities in Outokumpu at shallow depths $(0-100 \mathrm{~m}$; Itävaara et al., 2011), and at 200 and $2300 \mathrm{~m}$ depths (Nyyssönen et al., 2014). Additionally, Comamonadaceae were detected from other depths in the drill hole water column, such as at 1100$1500 \mathrm{~m}$ depth, which is characterized by ophiolitic rock sequence (Nyyssönen et al., 2014). However, Kietäväinen et al. (2013) detected substantial amounts of $\mathrm{H}_{2}$ only in fractures below $1500 \mathrm{~m}$ in Outokumpu, which might indicate that the source for $\mathrm{H}_{2}$ for abundant hydrogen oxidizers is in the bedrock aquifer that the 180 and/or $500 \mathrm{~m}$ fractures intersect or lead into. The seismic reflectors of Outokumpu bedrock demonstrate ophiolite-derived rock types in the vicinity of the drill hole, some of which are also located at shallow depths (Kukkonen et al., 2011). Thus, we assume that these 


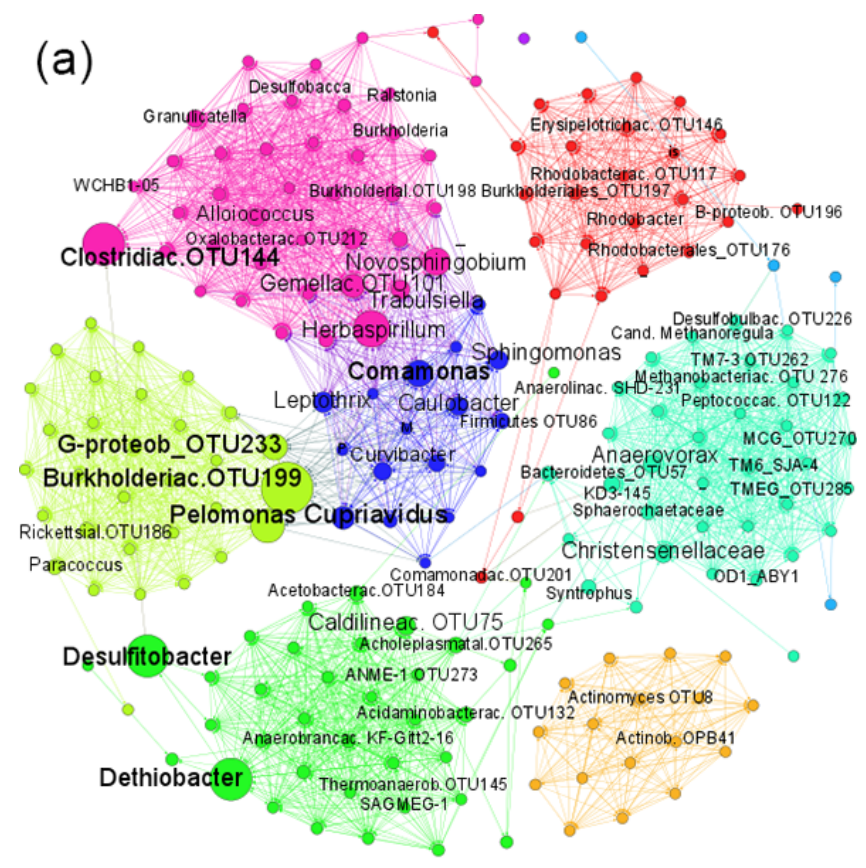

fracture was hydrogen-oxidizing Dethiobacter that has previously also been detected from groundwaters associated with ophiolitic rock sequence with active serpentinization processes (Tiago and Veríssimo, 2013). Brazelton et al. (2013) detected the acetyl-CoA synthase gene affiliating with $D e$ thiobacter from bacterial shotgun-sequenced metagenomes from bacterial Winter House Canyon (WHCB) samples from Tablelands Ophiolite. Moreover, similarities between serpentinizing environments and the deep biosphere of Outokumpu bedrock include the detection of abundant clostridial phylotypes such as Anaerobrancaceae from the deeper parts of the bedrock (Itävaara et al., 2011; Brazelton et al., 2013; Purkamo et al., 2013; Nyyssönen et al., 2014). The "keystone species" of the total and active microbial communities detected in this study reflect the similarity between the serpentinizing environments and Outokumpu deep biosphere with Comamonadaceae, Burkholderiaceae, Clostridiaceae and Dethiobacter as the recognized "keystone" families.

Overall, the spatial distribution of Burkholderiales at shallower depths and Clostridiales in the fractures located deeper in the bedrock can be explained to some level with the availability of electron acceptors. Both of these groups are able to use $\mathrm{H}_{2}$ as an electron donor, but Comamonadaceae are mainly aerobic chemoorganotrophs using a vide variety of different organic carbon compounds for energy and using oxygen as a terminal electron acceptor (Willems et al., 1991), while Dethiobacter is a strict anaerobe that reduces sulfur compounds but not sulfate (Sorokin et al., 2008). However, as their co-occurrence in the $1820 \mathrm{~m}$ fracture suggests, these organisms can prevail in the same environment. In Outokumpu, low concentrations of oxygen were measured during the pumping of the fracture fluids $\left(<0.1 \mathrm{mg} \mathrm{L}^{-1}\right.$ ) (Purkamo et al., 2013). While oxygen can be introduced into water due to the atmospheric contamination, small amounts of oxygen can be produced in radiolysis of water in bedrock (Pedersen, 1997; Lin et al., 2005). This might explain the detection of aerobic bacteria such as Comamonadaceae in the deep fluids of Outokumpu.

Higher hydrogen concentration in the two deepest fracture fluids (Kietäväinen et al., 2013) could indicate that something other than the electron donor is limiting the communities at these depths. Abundant bacterial groups of the communities in the $2260 \mathrm{~m}$ fracture belonged to Actinobacteria and $\alpha$-Proteobacteria. Little is known about metabolic capacities of the OPB41 candidate phylum, but as an actinobacterial phylotype, they may be chemoorganotrophs, while Bradyrhizobiaceae are mixotrophs with the capacity to oxidize $\mathrm{H}_{2}$. In this sample, $4.5 \%$ of the sequences affiliated with Streptophyta, representing likely plant material. Kietäväinen et al. (2013) reported that $2260 \mathrm{~m}$ depth contained up to $30 \%$ of residual drilling fluids, thus offering a possible explanation for these sequences. The source of this material can be peat that was used in the drilling mud as stabilizer during the drilling of shallower depths ( $<1000 \mathrm{~m}$; Ahonen et al., 2011). The drilling fluids are circulated in the system throughout the 
drilling operation; thus, a small fraction of this peat material may be present still at this depth.

The fractures located below $2 \mathrm{~km}$ depth, mostly dominated by unclassifiable phylotypes, might suggest that these depths harbour life that differs considerably from the currently known microorganisms.

\subsubsection{Comparison of the microbial community structure and functionality between different Precambrian deep subsurface sites}

Bacterial and archaeal communities from the Outokumpu fracture zones resemble the drill hole water communities described in a previous study (Nyyssönen et al., 2014). This is not surprising, as drill hole fluids are a mixture of the different fracture fluids emanating to the drill hole from the fractures at different depths of the bedrock. Comamonadaceae form a major part of the bacterial community at most depths in the drill hole, as they are abundant in 180, 500, 2260 and $2300 \mathrm{~m}$ fracture communities. At 967 and $1820 \mathrm{~m}$ fracture communities, phylotypes affiliating with Clostridiales are dominant, while clostridial phylotypes represent a major fraction of the drill hole communities at $1000-1500 \mathrm{~m}$. Many sulfate reducer phylotypes detected in this study were similar to those detected from the drill hole fluids (Itävaara et al., 2011; Purkamo et al., 2015) and from fracture zones (Purkamo et al., 2013) with DGGE. These included Desulfotomaculum and Desulfovibrio. Archaeal communities in the fractures and in the drill hole are mainly dominated by Methanobacterium, but SAGMEG archaea are also abundant in the drill hole communities at $1000 \mathrm{~m}$ and above (Nyyssönen et al., 2014), possibly originating from the $967 \mathrm{~m}$ fracture, where SAGMEG archaea were dominant in the total archaeal community.

Members of Comamonadaceae and Pseudomonadaceae belong to the core microbial community in Outokumpu. These were also detected from all studied microbial communities in another Fennoscandian crystalline bedrock environment in Olkiluoto fracture zones (Bomberg et al., 2015a). To emphasize the importance of these microbes to the total communities in deep crystalline bedrock environments, members of Comamonadaceae were recognized as the "keystone genera" of the active microbial community in the Outokumpu deep biosphere.

The microbial communities in Outokumpu deep crystalline bedrock share common features with those in the deep ecosystems in Witwatersrand Basin, South Africa. Clones affiliating with Comamonadaceae have been found in a deep drill hole outlet in Driefontein gold mine in South Africa. In addition, clostridial sulfate reducers, such as Desulfotomaculum, are dominant in the SRB communities in Outokumpu as well as the deep borehole communities in Driefontein (Baker et al., 2003; Moser et al., 2003, 2005; Silver et al., 2010). Candidatus Desulforudis audaxviator was a minor component (with 1-35\% relative abundance) of the SRB communi- ties in Outokumpu fractures at depths of 180-2260 m, in contrast to a microbial community where $D$. audaxviator formed a single-species ecosystem in deep bedrock fracture in Mponeng mine (Chivian et al., 2008).

The detection of a SAGMEG-dominated archaeal community in the $967 \mathrm{~m}$ fracture reinforces the results from previous study of Outokumpu deep fracture zone microbial communities (Purkamo et al., 2013). These archaea were first discovered in gold mines in South Africa (Takai et al., 2001) and recently named as Hadesarchaea (Baker et al., 2016). The first clues about the carbon metabolism of these archaea came from a study of deeply buried ocean sediment, where SAGMEG archaea were part of the mainly heterotrophic archaeal community (Biddle et al., 2006). A recent study of four genomic bins of Hadesarchaea revealed the metabolic diversity of this new archaeal lineage. Although they share several characteristics with other Euryarchaeota, they lack the marker genes for methanogenesis (Baker et al., 2016). Correspondingly, the predicted metagenome of the total archaeal community at $967 \mathrm{~m}$ with $94 \%$ of Hadesarchaea in our study demonstrated significantly lower number of methane metabolism genes than the other fracture fluid communities. The most probable energy-harvesting method for these archaea is thought to be the oxidation of carbon monoxide coupled with $\mathrm{H}_{2} \mathrm{O}$ reduction (Baker et al., 2016). Thus, we assume that, in Outokumpu subsurface, these archaea may fill the niche of carbon monoxide utilizers and produce $\mathrm{H}_{2}$ for hydrogenotrophic part of the microbial community.

Furthermore, this study supports the biogeographical trend that methanogens in different deep Precambrian sites are similarly distributed within depth (Kietäväinen and Purkamo, 2015). Methanogens with wider substrate range were found in the fractures located at shallower depths both in Outokumpu and several deep subsurface sites in South Africa. On the other hand, obligately hydrogenotrophic methanogens were detected in the fracture zones located deeper (Moser et al., 2005; Gihring et al., 2006; Lin et al., 2006). Archaeal communities represented much less diversity, and, interestingly, while almost all fracture zones were dominated by methanogenic archaea, the archaeal fracture community in the $180 \mathrm{~m}$ fracture was the most diverse, where, for example, archaea belonging to Miscellaneous Crenarchaeal Group (MCG) and Terrestrial Miscellaneous Euryarchaeal Group (TMEG) were detected. In Olkiluoto, the highest archaeal species richness was detected from a fracture at a depth of $296 \mathrm{~m}$ (Bomberg et al., 2015a). In another study of archaeal communities in Olkiluoto, some indication of correlation between increasing depth and decreasing diversity could be detected (Bomberg et al., 2015b). Low archaeal diversity may be due to the coverage of the primer pairs that were used in the nested PCR approach as well as the two-step PCR itself.

Many of the abundant bacterial groups in Outokumpu bedrock are organotrophic with capacity to use a wide range of substrates for biosynthesis and either fermentation or 
anaerobic respiration for energy conservation. Hence, depending on the available sources of energy and carbon, these organisms can switch to the best energy mechanism currently available. With the low relative abundance of the genes involved in autotrophic carbon fixation pathways in the predicted metagenomes, we propose that, in Outokumpu, heterotrophic carbon metabolism is also as important for the intrinsic fracture zone communities as it is for the drill hole water column communities (Purkamo et al., 2015). Archaeal communities in Outokumpu fracture zones are mainly methanogenic, most likely using the hydrogenotrophic methanogenesis pathway from $\mathrm{CO}_{2}$ to $\mathrm{CH}_{4}$.

\section{Conclusions}

The microbial communities of Outokumpu Precambrian crystalline bedrock fractures share features with serpenization-driven microbial communities in alkaline springs and subsurface aquifers. These include members belonging to Burkholderiales and Clostridia. Additionally, these phylotypes were regarded as the "keystone species" in the Outokumpu deep biosphere. Additionally, Comamonadaceae are part of the core microbial community in Fennoscandian crystalline bedrock environments. Sulfatereducing microbes and methanogens are present, but they represent marginal groups of the microbial communities. The dominant taxa of the sulfate-reducing communities observed in this study are similar to the ones detected from the deep subsurface of Driefontein mine in South Africa. Similarly, the total archaeal community at $967 \mathrm{~m}$ fracture is dominated by SAGMEG archaea, initially described at deep gold mines of South Africa. Otherwise, hydrogenotrophic methanogens, mainly Methanobacterium, dominate the archaeal communities. The fracture zone at $180 \mathrm{~m}$ in Outokumpu hosts the most diverse archaeal communities. Many probable "keystone species" of the Outokumpu deep biosphere belong to the rare biosphere, with low abundance but a wide range of carbon substrates and a capacity for $\mathrm{H}_{2}$ oxidation. Metagenomic predictions of the bacterial communities revealed that heterotrophy is also important in the deep fracture zones in Outokumpu.

\section{The Supplement related to this article is available online at doi:10.5194/bg-13-3091-2016-supplement.}

Author contributions. Lotta Purkamo planned and conducted the research, analysed the data and is the corresponding author. Malin Bomberg aided in planning, sampling, analysis of the data and writing the manuscript. Riikka Kietäväinen took part in sampling, provided hydrogeochemistry data and participated in writing the manuscript. Heikki Salavirta assisted in analysing the data and writing the manuscript. Mari Nyyssönen took part in sampling and writ- ing the manuscript. Maija Nuppunen-Puputti assisted in sampling and aided in laboratory research. Lasse Ahonen assisted in planning and executing the sampling and hydrogeochemistry analysis and writing the manuscript. Ilmo Kukkonen provided access to Outokumpu Deep Drill Hole, supported sampling, assisted in writing the manuscript and provided funding. Merja Itävaara took part in sampling and writing the manuscript and provided funding.

Acknowledgements. Mirva Pyrhönen is acknowledged for excellent laboratory skills and help in preparing the sampling trips. Arto Pullinen, Leea Ojala, Pauliina Rajala and Sirpa Jylhä are acknowledged for the professional sampling assistance at the Outokumpu field site. This study was funded by Kone Foundation, the Academy of Finland (DEEP LIFE project, grant no. 133348/2009), the Foundation for Research of Finnish Natural Resources (grant no. 1718/09) and the Finnish research programme on nuclear waste management (KYT, grants GEOMOL, KABIO, SALAMI and RENGAS).

Edited by: A. Ito

\section{References}

Ahonen, L., Kietäväinen, R., Kortelainen, N., Kukkonen, I. T., Pullinen, A., Toppi, T., Bomberg, M., Itävaara, M., Nousiainen, A., Nyyssönen, M., and Öster, M.: Hydrogeological characteristics of the Outokumpu Deep Drill Hole, edited by: Kukkonen, I. T., Geological Survey of Finland, Special Paper, 51, 151-168, 2011.

Altschul, S. F., Gish, W., Miller, W., Myers, E. W., and Lipman, D. J.: Basic local alignment search tool, J. Mol. Biol., 215, 403-410, 1990.

Amend, J. P. and Teske, A.: Expanding frontiers in deep subsurface microbiology, Palaeogeogr. Palaeocl., 219, 131-155, 2005.

Baker, B. J., Moser, D. P., MacGregor, B. J., Fishbain, S., Wagner, M., Fry, N. K., Jackson, B., Speolstra, N., Loos, S., and Takai, $\mathrm{K}$.: Related assemblages of sulphate-reducing bacteria associated with ultradeep gold mines of South Africa and deep basalt aquifers of Washington State, Environ. Microbiol., 5, 267-277, 2003.

Baker, B. J., Saw, J. H., Lind, A. E., Lazar C. S., Hinrichs, K.U., Teske, A. P., and Ettema, T. J. G.: Genomic inference of the metabolism of cosmopolitan subsurface Archaea, Hadesarchaea, Nat. Microbiol., 16002, doi:10.1038/nmicrobiol.2016.2, 2016.

Bano, N., Ruffin, S., Ransom, B., and Hollibaugh, J. T.: Phylogenetic composition of Arctic Ocean archaeal assemblages and comparison with Antarctic assemblages, Appl. Environ. Microbiol., 70, 781-789, 2004

Barberan, A., Bates, S., T., Casamayor, E., O., and Fierer, N.: Using network analysis to explore co-occurrence patterns in soil microbial communities, ISME J., 6, 343-351, 2012.

Barns, S. M., Fundyga, R. E., Jeffries, M. W., and Pace, N. R.: Remarkable archaeal diversity detected in a Yellowstone National Park hot spring environment, P. Natl. Acad. Sci. USA, 91, 16091613, 1994. 
Bastian, M., Heymann, S., and Jacomy, M.: Gephi: an open source software for exploring and manipulating networks, ICWSM, 8, 361-362, 2009.

Biddle, J. F., Lipp, J. S., Lever, M. A, Lloyd, K. G., Sørensen, K. B., Anderson, R., Fredricks, H. F., Elvert, M., Kelly, T. J., Schrag, D. P., Sogin, M. L., Brenchley, J. E., Teske, A., House, C. H., and Hinrichs, K.-U.: Heterotrophic Archaea dominate sedimentary subsurface ecosystems off Peru, P. Natl. Acad. Sci. USA, 10, 3846-3851, 2006.

Biddle, J. F., Fitz-Gibbon, S., Schuster, S. C., Brenchley, J. E., and House, C. H.: Metagenomic signatures of the Peru Margin subseafloor biosphere show a genetically distinct environment, $\mathrm{P}$. Natl. Acad. Sci. USA, 105, 10583-10588, 2008.

Biddle, J. F., White, J. R., Teske, A. P., and House, C. H.: Metagenomics of the subsurface Brazos-Trinity Basin (IODP site 1320): comparison with other sediment and pyrosequenced metagenomes, ISME J., 5, 1038-1047, 2011.

Blankenberg, D., Von Kuster, G., Coraor, N., Ananda, G., Lazarus, R., Mangan, M., Nekrutenko, A., and Taylor, J.: Galaxy: a web-based genome analysis tool for experimentalists, Curr. Protoc. Mol. Biol., 19, 19.10.1-19.10.21, doi:10.1002/0471142727.mb1910s89, 2010.

Blondel, V. D., Guillaume, J.-L., Lambiotte, R., and Lefebvre, E.: Fast unfolding of communities in large networks, Journal of Statistical Mechanics: Theory and Experiment, 2008.

Bomberg, M., Nyyssönen, M., Nousiainen, A., Hultman, J., Paulin, L., Auvinen, P., and Itävaara, M.: Evaluation of Molecular Techniques in Characterization of Deep Terrestrial Biosphere, Open Journal of Ecology, 4, 468-487, 2014.

Bomberg, M., Nyyssönen, M., Pitkänen, P., Lehtinen, A., and Itävaara, M.: Active Microbial Communities Inhabit SulphateMethane Interphase in Deep Bedrock Fracture Fluids in Olkiluoto, Finland, BioMed Research International, 2015a.

Bomberg, M., Lamminmäki, T., and Itävaara, M.: Estimation of microbial metabolism and co-occurrence patterns in fracture groundwaters of deep crystalline bedrock at Olkiluoto, Finland, Biogeosciences Discuss., 12, 13819-13857, doi:10.5194/bgd12-13819-2015, 2015b.

Brandes, U.: A Faster Algorithm for Betweenness Centrality, J. Math. Sociol., 25, 163-177, 2001.

Brazelton, W. J., Nelson, B., and Schrenk, M. O.: Metagenomic evidence for $\mathrm{H}_{2}$ oxidation and $\mathrm{H}_{2}$ production by serpentinitehosted subsurface microbial communities, Front. Microbiol., 2, 268, doi:10.3389/fmicb.2011.00268, 2012.

Brazelton, W. J., Morrill, P. L., Szponar, N., and Schrenk, M. O.: Bacterial communities associated with subsurface geochemical processes in continental serpentinite springs, Appl. Environ. Microbiol., 79, 3906-3916, doi:10.1128/AEM.00330-13, 2013.

Brown, M. V., Philip, G. K., Bunge, J. A., Smith, M. C., Bissett, A., Lauro, F. M., Fuhrman, J. A., and Donachie, S. P.: Microbial community structure in the North Pacific ocean, ISME J. 3, 1374-1386, doi:10.1038/ismej.2009.86, 2009.

Caporaso, J. G., Kuczynski, J., Stombaugh, J., Bittinger, K., Bushman, F. D., Costello, E. K., Fierer, N., Pena, A. G., Goodrich, J. K., and Gordon, J. I.: QIIME allows analysis of high-throughput community sequencing data, Nat. Methods, 7, 335-336, 2010.

Chivian, D., Brodie, E. L., Alm, E. J., Culley, D. E., Dehal, P. S., DeSantis, T. Z., Gihring, T. M., Lapidus, A., Lin, L. H., Lowry, S. R., Moser, D. P., Richardson, P. M., Southam, G., Wanger,
G., Pratt, L. M., Andersen, G. L., Hazen, T. C., Brockman, F. J., Arkin, A. P., and Onstott, T. C.: Environmental genomics reveals a single-species ecosystem deep within Earth, Science, 322, 275 278, doi:10.1126/science.1155495, 2008.

Dworkin, E., Falkow, S., Rosenberg, E., Schleifer, K.-H., Stackebrandt, E. (Eds.): The Prokaryotes, A Handbook on the Biology of Bacteria, Springer, New York, NY, USA, 2006.

Edwars, U., Rogall, T., Blocker, H., Emde, M., and Bottger, E. C.: Isolation and direct complete nucleotide determination of entire genes. Characterization of a gene coding for $16 \mathrm{~S}$ ribosomal RNA, Nucleic Acids Res., 17, 7843-7853, 1989.

Etiope, G. and Sherwood Lollar, B.: Abiotic methane on Earth, Rev. Geophys., 51, 276-299, 2013.

Fish, J. A., Chai, B., Wang, Q., Sun, Y., Brown, C. T., Tiedje, J. M., and Cole, J. R.: FunGene: the Functional Gene Pipeline and Repository, Front. Microbiol., 4, 291, doi:10.3389/fmicb.2013.00291, 2013.

Geets, J., Borremans, B., Diels, L., Springael, D., Vangronsveld, J., van der Lelie, D., and Vanbroekhoven, K.: DsrB gene-based DGGE for community and diversity surveys of sulfate-reducing bacteria, J. Microbiol. Methods, 66, 194-205, 2006.

Giardine, B., Riemer, C., Hardison, R. C., Burhans, R., Elnitski, L., Shah, P., Zhang, Y., Blankenberg, D., Albert, I., Taylor, J., Miller, W., Kent, W. J., and Nekrutenko, A.: Galaxy: a platform for interactive large-scale genome analysis, Genome Res., 15, 14511455, 2005.

Gihring, T., Moser, D., Lin, L. H., Davidson, M., Onstott, T., Morgan, L., Milleson, M., Kieft, T., Trimarco, E., and Balkwill, D.: The distribution of microbial taxa in the subsurface water of the Kalahari Shield, South Africa, Geomicrobiol. J., 23, 415-430, 2006.

Goecks, J., Nekrutenko, A., Taylor, J., and The Galaxy Team: Galaxy: a comprehensive approach for supporting accessible, reproducible, and transparent computational research in the life sciences, Genome Biol., 11, R86, doi:10.1186/gb-2010-11-8r86, 2010.

Gold, T.: The deep, hot biosphere, P. Natl. Acad. Sci. USA, 89, 6045-6049, 1992.

Grosskopf, R., Janssen, P. H., and Liesack, W.: Diversity and structure of the methanogenic community in anoxic rice paddy soil microcosms as examined by cultivation and direct 16S rRNA gene sequence retrieval, Appl. Environ. Microbiol., 64, 960-969, 1998.

Hales, B. A., Edwards, C., Ritchie, D. A., Hall, G., Pickup, R. W., and Saunders, J. R.: Isolation and identification of methanogenspecific DNA from blanket bog peat by PCR amplification and sequence analysis, Appl. Environ. Microbiol., 62, 668-675, 1996.

Hallbeck, L. and Pedersen, K.: Characterization of microbial processes in deep aquifers of the Fennoscandian Shield, Appl. Geochem., 23, 1796-1819, 2008.

Hallbeck, L. and Pedersen, K.: Culture-dependent comparison of microbial diversity in deep granitic groundwater from two sites considered for a Swedish final repository of spent nuclear fuel, FEMS Microbiol. Ecol., 81, 66-77, 2012.

Hammer, Ø., Harper, D., and Ryan, P.: Past: Paleontological Statistics Software Package for education and data analysis, Paleontología Electrónica, 4, 1-9, 2001. 
Itävaara, M., Nyyssönen, M., Kapanen, A., Nousiainen, A., Ahonen, L., and Kukkonen, I.: Characterization of bacterial diversity to a depth of $1500 \mathrm{~m}$ in the Outokumpu deep borehole, Fennoscandian Shield, FEMS Microbiol. Ecol., 77, 295-309, 2011.

Kietäväinen, R. and Purkamo, L.: The origin, source and cycling of methane in deep crystalline rock biosphere, Front. Microbiol., 6, 725, doi:10.3389/fmicb.2015.00725, 2015.

Kietäväinen, R., Ahonen, L., Kukkonen, I. T., Hendriksson, N., Nyyssönen, M., and Itävaara, M.: Characterisation and isotopic evolution of saline waters of the Outokumpu Deep Drill Hole, Finland-Implications for water origin and deep terrestrial biosphere, Appl. Geochem., 32, 37-51, 2013.

Kukkonen, I. T., Rath, V., Kivekäs, L., Šafanda, J., and Čermák, V.: Geothermal studies of the Outokumpu deep drill hole, Outokumpu Deep Drilling Project 2003-2010, edited by: Kukkonen, I. T., Geological Survey of Finland, Special Paper, 51, 181-198, 2011.

Lambiotte, R., Delvenne, J.-C., and Barahona, M.: Laplacian Dynamics and Multiscale Modular Structure, Networks, 2009.

Langille, M. G., Zaneveld, J., Caporaso, J. G., McDonald, D., Knights, D., Reyes, J. A., Clemente, J. C., Burkepile, D. E., Thurber, R. L. V., and Knight, R.: Predictive functional profiling of microbial communities using 16S rRNA marker gene sequences, Nat. Biotechnol., 31, 814-821, 2013.

Lau, M. C., Cameron, C., Magnabosco, C., Brown, C. T., Schilkey, F., Grim, S., Hendrickson, S., Pullin, M., Lollar, B. S., and van Heerden, E.: Phylogeny and phylogeography of functional genes shared among seven terrestrial subsurface metagenomes reveal $\mathrm{N}$-cycling and microbial evolutionary relationships, Front. Microbiol., 5, 531, doi:10.3389/fmicb.2014.00531, 2014.

Lin, L., Hall, J., Lippmann-Pipke, J., Ward, J. A., Sherwood Lollar, B., DeFlaun, M., Rothmel, R., Moser, D., Gihring, T. M., and Mislowack, B.: Radiolytic $\mathrm{H}_{2}$ in continental crust: nuclear power for deep subsurface microbial communities, Geochem. Geophys. Geosyst., 6, Q07003, doi:10.1029/2004GC000907, 2005.

Lin, L., Hall, J., Onstott, T., Gihring, T., Lollar, B. S., Boice, E., Pratt, L., Lippmann-Pipke, J., and Bellamy, R. E.: Planktonic microbial communities associated with fracture-derived groundwater in a deep gold mine of South Africa, Geomicrobiol. J., 23, 475-497, 2006.

Lupatini, M., Suleiman, A. K., Jacques, R. J., Antoniolli, Z. I., de Siqueira Ferreira, A., Kuramae, E. E., and Roesch, L. F.: Network topology reveals high connectance levels and few key microbial genera within soils, Front. Environ. Sci., 2, 10, doi:10.3389/fenvs.2014.00010, 2014.

Magnabosco, C., Ryan, K., Lau, M. C., Kuloyo, O., Sherwood Lollar, B., Kieft, T. L., van Heerden, E., and Onstott, T.: A metagenomic window into carbon metabolism at $3 \mathrm{~km}$ depth in Precambrian continental crust, ISME J., 10, 730-741, 2016.

McCollom, T. M.: Laboratory simulations of abiotic hydrocarbon formation in Earth's deep subsurface, Rev. Mineral. Geochem., 75, 467-494, doi:10.2138/rmg.2013.75.15, 2013.

McCollom, T. M., Lollar, B. S., Lacrampe-Couloume, G., and Seewald, J. S.: The influence of carbon source on abiotic organic synthesis and carbon isotope fractionation under hydrothermal conditions, Geochim. Cosmochim. Ac., 74, 2717-2740, 2010.
McMahon, S. and Parnell, J.: Weighing the deep continental biosphere, FEMS Microbiol. Ecol., 87, 113-120, doi:10.1111/15746941.12196, 2014.

Moser, D., Onstott, T., Fredrickson, J., Brockman, F., Balkwill, D., Drake, G., Pfiffner, S., White, D., Takai, K., and Pratt, L.: Temporal shifts in microbial community structure and geochemistry of an ultradeep South African gold mine borehole, Geomicrobiol. J., 20, 517-548, 2003.

Moser, D. P., Gihring, T. M., Brockman, F. J., Fredrickson, J. K., Balkwill, D. L., Dollhopf, M. E., Lollar, B. S., Pratt, L. M., Boice, E., Southam, G., Wanger, G., Baker, B. J., Pfiffner, S. M., Lin, L. H., and Onstott, T. C.: Desulfotomaculum and Methanobacterium spp. dominate a 4- to 5-kilometer-deep fault, Appl. Environ. Microbiol., 71, 8773-8783, 2005.

Mu, A., Boreham, C., Leong, H. X., Haese, R. R., and Moreau, J. W.: Changes in the deep subsurface microbial biosphere resulting from a field-scale $\mathrm{CO}_{2}$ geosequestration experiment, Front. Microbiol., 5, 209, doi:10.3389/fmicb.2014.00209, 2014.

Muyzer, G., de Waal, E. C., and Uitterlinden, A. G.: Profiling of complex microbial populations by denaturing gradient gel electrophoresis analysis of polymerase chain reaction-amplified genes coding for 16S rRNA, Appl. Environ. Microbiol., 59, 695700, 1993.

Nealson, K., H., Inagaki, F., and Takai, K.: Hydrogen-driven subsurface lithoautotrophic microbial ecosystems (SLiMEs): do they exist and why should we care?, Trends Microbiol., 13, 405-410, doi:10.1016/j.tim.2005.07.010, 2005.

Nyyssönen, M., Bomberg, M., Kapanen, A., Nousiainen, A., Pitkänen, P., and Itävaara, M.: Methanogenic and sulphate-reducing microbial communities in deep groundwater of crystalline rock fractures in Olkiluoto, Finland, Geomicrobiol. J., 29, 863-878, 2012.

Nyyssönen, M., Hultman, J., Ahonen, L., Kukkonen, I., Paulin, L., Laine, P., Itävaara, M., and Auvinen, P.: Taxonomically and functionally diverse microbial communities in deep crystalline rocks of the Fennoscandian shield, ISME J., 8, 126-138, doi:10.1038/ismej.2013.125, 2014.

Osburn, M. R., LaRowe, D. E., Momper, L. M., and Amend, J. P.: Chemolithotrophy in the continental deep subsurface: Sanford Underground Research Facility (SURF), USA, Front. Microbiol., 5, 610, doi:10.3389/fmicb.2014.00610, 2014.

Paine, R. T.: A Conversation on Refining the Concept of Keystone Species, Conserv. Biol., 9, 962-964, 1995.

Pedersen, K.: Microbial life in deep granitic rock, FEMS Microbiol. Rev., 20, 399-414, 1997.

Pedersen, K.: Exploration of deep intraterrestrial microbial life: current perspectives, FEMS Microbiol. Lett., 185, 9-16, 2000.

Pedersen, K.: Investigations of subterranean bacteria in deep crystalline bedrock and their importance for the disposal of nuclear waste, Can. J. Microbiol., 42, 382-391, 1996.

Pedersen, K., Arlinger, J., Eriksson, S., Hallbeck, A., Hallbeck, L., and Johansson, J.: Numbers, biomass and cultivable diversity of microbial populations relate to depth and borehole-specific conditions in groundwater from depths of 4-450 $\mathrm{m}$ in Olkiluoto, Finland, ISME J., 2, 760-775, 2008.

Power, M. E., Tilman D., Estes, J. A., Menge, B. A., Bond, W. J., Mills, L. S., Gretchen, D., Castilla, J. C., Lubchenco, J., and Paine, R. T.: Challenges in the quest for keystones, BioScience, 4, 609-620, 1996. 
Proskurowski, G., Lilley, M. D., Seewald, J. S., Fruh-Green, G. L., Olson, E. J., Lupton, J. E., Sylva, S. P., and Kelley, D. S.: Abiogenic hydrocarbon production at lost city hydrothermal field, Science, 319, 604-607, doi:10.1126/science.1151194, 2008.

Purkamo, L., Bomberg, M., Nyyssönen, M., Kukkonen, I., Ahonen, L., Kietäväinen, R., and Itävaara, M.: Dissecting the deep biosphere: retrieving authentic microbial communities from packerisolated deep crystalline bedrock fracture zones, FEMS Microbiol. Ecol., 85, 324-337, 2013.

Purkamo, L., Bomberg, M., Nyyssönen, M., Kukkonen, I., Ahonen, L., and Itävaara, M.: Heterotrophic Communities Supplied by Ancient Organic Carbon Predominate in Deep Fennoscandian Bedrock Fluids, Microb. Ecol., 69, 319-332, doi:10.1007/s00248-014-0490-6, 2015.

Quince, C., Lanzén, A., Curtis, T. P., Davenport, R. J., Hall, N., Head, I. M., Read, L. F., and Sloan, W. T.: Accurate determination of microbial diversity from 454 pyrosequencing data, Nat. Methods, 6, 639-641, 2009.

Schloss, P. D., Westcott, S. L., Ryabin, T., Hall, J. R., Hartmann, M., Hollister, E. B., Lesniewski, R. A., Oakley, B. B., Parks, D. H., and Robinson, C. J.: Introducing mothur: open-source, platformindependent, community-supported software for describing and comparing microbial communities, Appl. Environ. Microbiol., 75, 7537-7541, 2009.

Schrenk, M. O., Brazelton, W. J., and Lang, S. Q.: Serpentinization, carbon, and deep life, Rev. Mineral. Geochem., 75, 575606, doi:10.2138/rmg.2013.75.18, 2013.

Silver, B., Onstott, T., Rose, G., Lin, L. H., Ralston, C., SherwoodLollar, B., Pfiffner, S., Kieft, T., and McCuddy, S.: In situ cultivation of subsurface microorganisms in a deep mafic sill: implications for SLiMEs, Geomicrobiol. J., 27, 329-348, 2010.

Sogin, M. L., Morrison, H. G., Huber, J. A., Mark Welch, D., Huse, S. M., Neal, P. R., Arrieta, J. M., and Herndl, G. J.: Microbial diversity in the deep sea and the underexplored "rare biosphere", P. Natl. Acad. Sci. USA, 103, 12115-12120, 2006.

Sorokin, D. Y., Tourova, T. P., Mußmann, M., and Muyzer, G.: Dethiobacter alkaliphilus gen. nov. sp. nov., and Desulfurivibrio alkaliphilus gen. nov. sp. nov.: two novel representatives of reductive sulfur cycle from soda lakes, Extremophiles, 12, 431-439, 2008.
Stahl, D.: Development and application of nucleic acid probes, $\mathrm{Nu}-$ cleic acid techniques in bacterial systematics, 1991.

Steele, J. A., Countway, P. D., Xia, L., Vigil, P. D., Beman, J. M., Kim, D. Y., Chow, C. E., Sachdeva, R., Jones, A. C., Schwalbach M. S., Rose, J. M., Hewson, I., Patel, A., Sun, F., Caron, D. A., and Fuhrman, J. A.: Marine bacterial, archaeal and protistan association networks reveal ecological linkages, ISME J., 9, 1414-1425, 2011.

Szponar, N., Brazelton, W. J., Schrenk, M. O., Bower, D. M., Steele, A., and Morrill, P. L.: Geochemistry of a continental site of serpentinization, the Tablelands Ophiolite, Gros Morne National Park: a Mars analogue, Icarus, 224, 286-296, 2013.

Teske, A. and Sørensen, K. B.: Uncultured archaea in deep marine subsurface sediments: have we caught them all?, ISME J., 2, 3$18,2008$.

Tiago, I. and Veríssimo, A.: Microbial and functional diversity of a subterrestrial high $\mathrm{pH}$ groundwater associated to serpentinization, Environ. Microbiol., 15, 1687-1706, 2013.

Wang, Y. and Qian, P.-Y.: Conservative fragments in bacterial $16 \mathrm{~S}$ rRNA genes and primer design for 16S ribosomal DNA amplicons in metagenomic studies, PLoS ONE, 4, e7401, doi:10.1371/journal.pone.0007401, 2009.

Wagner, M., Roger, A. J., Flax, J. L., Brusseau, G. A., and Stahl, D. A.: Phylogeny of dissimilatory sulfite reductases supports an early origin of sulfate respiration, J. Bacteriol., 180, 2975-2982, 1998.

Whitman, W. B., Coleman, D. C., and Wiebe, W. J.: Prokaryotes: The unseen majority, P. Natl. Acad. Sci. USA, 95, 6576583,1998

Willems, A., De Ley, J., Gillis, M., and Kersters, K.: Comamonadaceae, a New Family Encompassing the Acidovorans rRNA Complex, Including Variovorax paradoxus gen. nov. comb. nov. for Alcaligenes paradoxus (Davis 1969), Int. J. Syst. Bact, 445450, 1991.

Zhou, J., Deng, Y., Luo, F., He, Z., and Yang, Y.: Phylogenetic molecular ecological network of soil microbial communities in response to elevated $\mathrm{CO}_{2}$, MBio, 2, doi:10.1128/mBio.00122$11,2011$. 